\title{
Ameghino en contexto. Nuevos datos históricos y revisión geoarqueológica del sitio Arroyo Frías (1870 - 1874). Mercedes, provincia de Buenos Aires, Argentina
}

\author{
Marcelo Javier TOLEDO \\ loessoide@gmail.com
}

\begin{abstract}
Ameghino in context. Historical and geoarchaeological review of the Arroyo Frías site (1870 - 1874). Mercedes, province of Buenos Aires, Argentina. In 1881 Ameghino described the fossil human remains of Arroyo Frías as its more relevant finding, considering it to be the oldest of Pampean sites since the remains were unearthed from his Pliocene Upper Pampean. He realized this finding by the end of 1872 , announces it to Burmeister in January of 1874 and, in September he continued the excavation with professor Ramorino. In spite of that, he will not obtain any official recognition since, in 1876, the commissioners of the Sociedad Científica Argentina explored the area of the Cañada de Rocha creek, believing they were in the Frías valley. Victims of this confusion Moreno, Zeballos and Lista declared that Ameghino mistakenly attributed an older "diluvian" age to very recent geologic layers, strongly eroding his reputation and scientific credibility. It is analyzed here the historical context of this disagreement that stigmatized for decades the archeological prospection of Pampean plains, while we present a geologic model with new ${ }^{14} \mathrm{C}$ and OSL dates, in order to understand why Ameghino erroneously attributed a great antiquity to these layers. Also arise other geoarchaeological issues when these new data are confronted with the detailed descriptions of this author.
\end{abstract}

Key Words: Ameghino, Frías, Lujanian, Zeballos, Pampean

Resumen: En 1881 Ameghino describió los restos humanos del arroyo Frías como su descubrimiento más importante ya que lo consideraba el más antiguo al atribuirlo a su Pampeano Superior de edad pliocena. Realizó este hallazgo a fines de 1872, lo presenta a Burmeister en enero de $1874 \mathrm{y}$, en septiembre del mismo año excava junto al Profesor Ramorino. A pesar de ello, no obtendrá ningún reconocimiento oficial ya que, en 1876 los comisionados de la Sociedad Científica Argentina inspeccionan la Cañada de Rocha, confundiéndola con el arroyo Frías. Víctimas de esta confusión Moreno, Zeballos y Lista afirmarán erróneamente que Ameghino consideró "diluvianas" a capas geológicas muy recientes, privándolo de credibilidad frente a los círculos científicos porteños. Se analiza el contexto histórico de este desencuentro que estigmatizó por décadas la prospección de la llanura pampeana y se presenta un modelo geológico, más dataciones ${ }^{14} \mathrm{C}$ y OSL, que permiten comprender por qué Ameghino le atribuyó a estos restos gran antigüedad. Además, esos nuevos datos plantean otros interrogantes geoarqueológicos al confrontarlos con las detalladas descripciones de este autor.

Palabras clave: Ameghino, Frías, Lujanense, Zeballos, pampeano.

\section{INTRODUCCIÓN}

Entre 1869 y 1877 Ameghino exhumó en sus célebres "paraderos" del valle del río Luján restos óseos de megafauna en los cuales cree ver modificaciones de origen antrópico. Reunió todas estas observaciones en su Antigüedad del Hombre en el Plata (1880b-1881), las que nunca fueron reevaluadas, ya que se consideraron como errores de apreciación, sobre supuesto material reciente, fruto de inquietudes y pasiones de un joven sin formación académica.

El término "paradero" fue dado por los co- lonos españoles de Carmen de Patagones a sitios superficiales con abundantes lascas y restos de artefactos líticos, pero sin enterratorios. Strobel (1867, 1872) lo incorporó a la literatura científica con el sentido de una estación o sitio prehistórico:

"ebbi la suerte de scoprire gli avanzi di un paradero ossia di una stazione prehistorica degli indiani tehielches o Patagoni" (Strobel 1867:166) 
En 1872 completó la descripción dándole un carácter de sitio superficial:

"Paradero o luogo ove si fa sosta. Tal
nome fu dato a questi depositi dagli
spagnuoli testimoni della formazione dei
paraderos continuata nell'epoca storica"

Moreno lo retoma en 1874 , lo extiende a la Provincia de Buenos Aires y Ameghino lo adapta y aplica al área del río Luján y afluentes, llamando así a todo sector de afloramiento, en las barrancas y en superficie, con restos que considera antrópicos (Ameghino 1879a). Al término recuperado por Strobel en Patagonia norte, Ameghino le da una dimensión estratigráfica (Fernández, 1982; Stagnaro, 1993), en particular en sus "paraderos eolíticos", los más antiguos y los que más le interesaban ya que probaban la existencia del hombre en su "Plioceno" pampeano (Ameghino, 1881). Luego de describir la geología de los depósitos lacustres de su "temps de grands lacs" dice:

"C'est dans ces anciens marais que j'ai trouvé presque tous les objets qui prouvent la contemporanéité de l'homme avec les mammifères éteints de la Plata. Chaque marais dans lequel j'ai trouve quelque chose indiquant la présence de l'homme a cette époque, constituera, pour moi, une station paléolithique " (Ameghino, 1879a:242)

Así, cada paradero no es más que una referencia material, estratigráfica y geográfica, para definir sus unidades de análisis que son las cronologías relativas de las asociaciones culturales y su correlato estratigráfico. De este modo reúne a estos sitios en grupos caracterizados por edades y complejidad creciente de la mano de paradigmas transformistas (eolíticos, mesolíticos y neolíticos) y que se corresponden con los depósitos "pampeanos", "pampeano lacustres" "postpampeanos" y "aluvionales".

En la literatura científica uno de los últimos en aplicar y discutir este término es Outes (1897) que vuelve a una mirada horizontalista, en línea con la tradición de Moreno y Zeballos, despojada de verticalidad estratigráfica y con ello de profundidad temporal. El vocablo "paradero", hecho popular por las publicaciones de Ameghino, subsiste hasta fines del siglo XX, entre los "neo-ameghinistas" (sensu Toledo 2009:196, 2011:134), quienes se forman y guían por las descripciones de la "Antigüedad del Hombre en el Plata”. Aquí nuevamente el término retoma su significación estratigráfica (e.g. Mignone, 1941).

Ameghino (1876, 1878, 1879 a y b, 1880a, $1880 \mathrm{~b}, 1881,1889$ ) halla en sus "paraderos" numerosos restos óseos de fauna extinta, estriados y fracturados, junto a artefactos líticos con ninguna o escasa modificación. Estos elementos, para los paraderos "eolíticos", los extrae de su capa "Lujanense" que atribuye al Plioceno y más tarde al Cuaternario (fig. 1). Observa que a medida que los estratos son más jóvenes las asociaciones faunísticas varían y que aumenta el grado de complejidad en la formatización de los líticos y, según los cánones del paradigma evolucionista cultural, asigna edades relativas a sus paraderos definiendo tres tipos según la nomenclatura europea de Lubock (1865): "Paleolíticos", "Mesolíticos" y "Neolíticos" (Ameghino, 1878, 1879b). Más tarde remplaza el nombre a los sitios "Paleolíticos" por "Eolíticos", siguiendo a de De Mortillet (1873), ya que no encuentra formas asimilables al tipo "acheulense o chellense" que caracterizaba en Europa al Paleolítico (Ameghino, 1881:540-541), formas que si cree reconocer posteriormente en La Plata en su "querandinense" (Ameghino, 1889:54).

Según la posición estratigráfica de sus hallazgos entre Luján y Mercedes, define como "eolíticos" a los "paraderos" de: Frías (№ 7), Frías (№ 6), Díaz (№ 5), Achával (№ 4), Cañón (№ 3), Luján (№ 2) y Frías (№ 1), descriptos en orden numérico inverso es decir, desde el más reciente $\left(\mathrm{N}^{\circ} 7\right)$ al más antiguo $\left(\mathrm{N}^{\circ} 1\right)$ (Fig. 1 y 2$)$. En una obra póstuma y trunca (en Torcelli 1935) agregó dos sitios de edad "pampeana superior": el "Yacimiento de Jáuregui" que ubicamos en el actual arroyo Muñiz y la "estación bonaerense" en el actual arroyo "El Chano" (Fig. 2).

Ameghino descubre, explora y estudia estos sitios fundamentalmente entre 1870 y 1877 siendo probablemente los años más fructíferos los comprendidos entre fines de 1873 y mediados de 1876. Para sus sitios más antiguos o "eolíticos", con evidencias de coexistencia del hombre con fauna extinta, ya posee un corpus factual e intelectual bien definido hacia fines de 1875 con partes considerables de sus memorias y de varios capítulos de la Antigüedad del Hombre en el Plata ya redactadas. Luego de una primera exposición en la arena publica en 1875 con una mención en un concurso de la Sociedad Científica Argentina, pasara todo el año de 1876 en pos de la certificación y aceptación de sus hallazgos por los círculos científicos dominantes que rechazan 


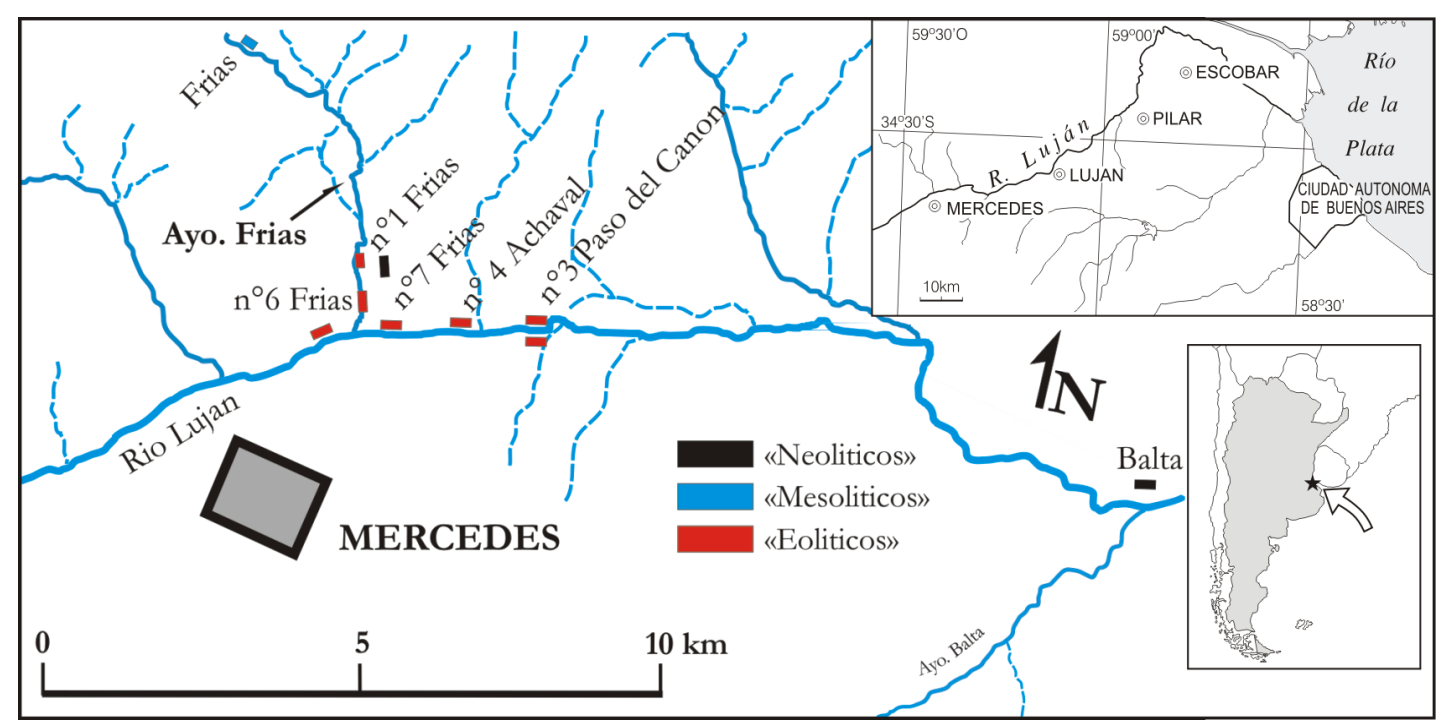

Fig. 1. Localización esquemática de los "Paraderos" de Ameghino (1881) en el valle del río Luján para el sector cercano a la ciudad de Mercedes.

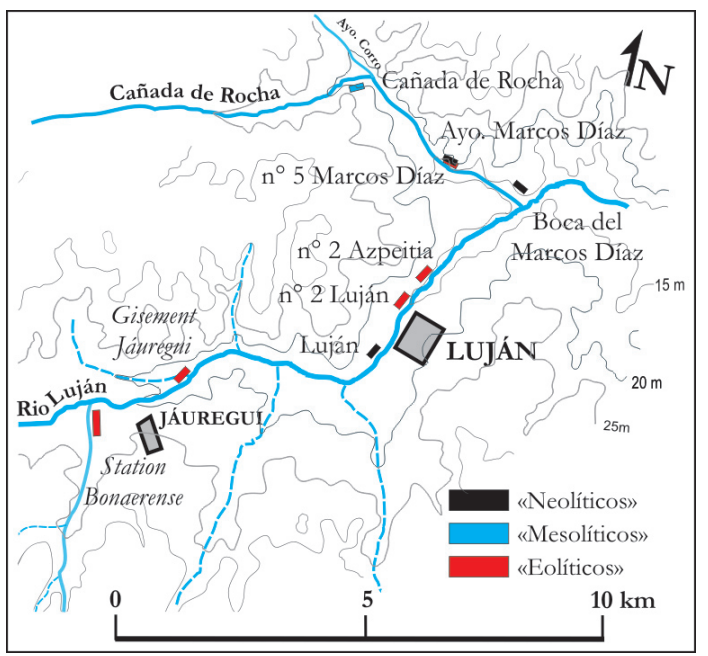

Fig. 2. Localización esquemática de los "Paraderos" de Ameghino (1881) en el área de Luján y Cañada de Rocha.

sus presentaciones o dilatan sus veredictos. En el marco del estudio contextual integral, es decir incluyendo los factores histórico-sociales, los elementos materiales geoarqueológicos y su interpretación pasada y presente de todos estos sitios, seleccionamos en este trabajo la presentación del análisis de este entramado para el Paradero $\mathrm{N}^{\circ}$ 1 (Arroyo Frías). Epistemológicamente no podemos disociar los lugares y materiales exhumados, las lecturas de tratados europeos, el contexto espacial y social, eventuales alianzas y la relación de tensión a ruptura, con los sistemas sociales de la ciencia central. Hasta su retorno de Paris en 1881 Ameghino interactuó con estos últimos sin lograr ser parte de ellos y tener sus hallazgos e ideas examinadas, y menos aún, aceptadas.

En este trabajo nos concentraremos entonces en el análisis del contexto histórico, geográfico y geoarqueológico del "Paradero de Frías o $\mathrm{N}^{\circ}$ 1 " ya que también es el único donde encuentra restos humanos y lo considera el más antiguo de todos, de edad "pampeana" o pliocena, constituyendo el germen, aun no confesado, de su futura teoría antropogénica.

\section{MATERIALES Y MÉTODOS}

La ubicación geográfica de estos sitios se determinó siguiendo las descripciones de Ameghino (1880b, 1881) en catastros históricos y mensuras antiguas georeferenciadas donde se reconocen topónimos y nombres de la época a los que este autor hace referencia. Se realizaron controles cruzados con cartas topográficas actuales, fotos aéreas y satelitales, y reconocimiento in situ.

Se identificó en afloramientos la estratigrafía definida en 1880-1881, y luego de un análisis secuencial y de dataciones AMS, OSL y ESR, se asignó a los sitios un rango de edades numéricas (Toledo, 2005, 2011).

Se complementó el abundante material histórico de las Obras Completas y Correspondencia Científica (OCyCC) de Ameghino compiladas por Torcelli (1935) con material original del Archivo y Biblioteca E. Zeballos (AyBEZ), Archivo Histórico 
de Geodesia de La Plata (AHG) y Biblioteca y Archivo Furt (BAF). La colección arqueológica Ameghino, de reciente catalogación, se estudió en el Museo de La Plata (MLP-ar-Colección Ameghino, depósito 25).

Este trabajo se inserta en un proyecto de investigación iniciado en 2003 que tiene por objetivo la revaluación geoarqueológica e histórica de las actividades de Ameghino entre 1869 y 1884 en el valle del Luján y la revisión de su aporte a la cuestión del poblamiento temprano (Toledo, 2005, 2009, 2011).

\section{RESULTADOS}

\section{El "paradero $N^{\circ} 1$ " y el "Hombre Fósil" de Mercedes, 1873}

En particular, Ameghino (1876, 1881) explora y describe con gran detalle la estratigrafía y contenido de los sitios № 1 (Frías) y № 2 (Luján) ya que los considera los más antiguos y los que mayores y evidentes pruebas aportaban a su hipótesis de hombre "plioceno". Así es que al "Paradero $\mathrm{N}^{\circ} 1$ le dedica un capítulo entero de "La Antigüedad del hombre en el Plata". Le asigna el $\mathrm{N}^{\circ} 1$ pues lo considera el más importante $\mathrm{y}$ considerablemente más antiguo que los demás, ya que posee dos particularidades que juzga excepcionales: por un lado es el único paradero en el que encuentra restos fósiles humanos y, por otro, los restos provendrían de las capas loessoides rojizas que supone del "pampeano superior" y de edad pliocena, y, por lo tanto, considerablemente más temprano que los depósitos verdosos de su "pampeano lacustre" del sitio $\mathrm{N}^{\circ} 2 \mathrm{y}$ de todos los otros "paraderos". Ameghino describió como "blanquizcos » a estos depósitos en sus primeras publicaciones y a partir de 1884 los adjetiva como "verdosos". Estos sedimentos tienen tonalidades más claras cuando secos y en húmedo son de color verde oliva.

Las circunstancias históricas del hallazgo son bien conocidas ya que fueron publicadas por Ameghino en varias oportunidades y replicadas por numerosos autores así que aquí haremos una breve reseña de los eventos más relevantes y nos concentraremos sobre los aspectos problemáticos, los menos conocidos y su contraste con nuevos datos de archivo y de campo.

\section{El hallazgo}

Ameghino realizó un primer hallazgo siendo muy joven, en 1870, en sus recorridas habituales en los alrededores de Mercedes (Ameghino, 1889;
Torcelli, 1935). Correspondería a un esqueleto completo y articulado extraído a nivel del agua del arroyo Frías (Frías I). Entre diciembre de 1872 y el verano de 1873 , con más experiencia, vuelve al mismo sitio, encuentra restos humanos desarticulados a mayor profundidad y mezclados con carbón, artefactos y fauna. Realiza una excavación exhaustiva de grandes dimensiones, ayudado por peones (Frías II). El profesor de la Universidad de Buenos Aires Giovanni Ramorino lo aconseja y asiste a las excavaciones (Ameghino 1881, Fernandez 1982). Lehmann-Nitsche (1907), Hrdlicka (1912) y más recientemente Orquera (1970, 1971) detallaron y analizaron los pormenores de ambos descubrimientos. Politis et al. (2011) dataron los restos de Frías II, por AMS, en $10.300 \pm 60 \mathrm{C} 14 \mathrm{AP}$ y $9.520 \pm 75 \mathrm{C} 14 \mathrm{AP}$.

\section{Localización}

En cuanto a la localización Ameghino, sin mayores precisiones, dice que el punto de hallazgo está:

"[...] situé dans la rive gauche $d u$ petit ruisseau de Frías, près du pont qu'on a construit tout récemment [...]" (Ameghino 1879:244)

"[...] situado sobre la margen izquierda del arroyo Frías, cerca del puente que allí fue construido recientemente." (Ameghino 1881:483)

No proporciona mejores datos como suele hacerlo este autor, por ejemplo, indicando la distancia aguas arriba o abajo de referencias geográficas como desembocaduras o bifurcaciones, o en este caso al puente mismo, que no está construido en 1873 cuando hace sus excavaciones. En 1889 agrega:

"En los alrededores de Mercedes [...], a unos 3 o 4 kilómetros de la ciudad, sobre el arroyo Frías, no lejos del puente construido sobre el mismo arroyo [...]" (Ameghino 1889:65)

El puente es el de la senda para caballos y carruajes de Mercedes a San Andrés de Giles. Con el estudio de planos catastrales antiguos se advierte que la posición del camino y su vado evolucionan en el tiempo. Para acotar la posición del sitio nos concentramos en identificar el puente 


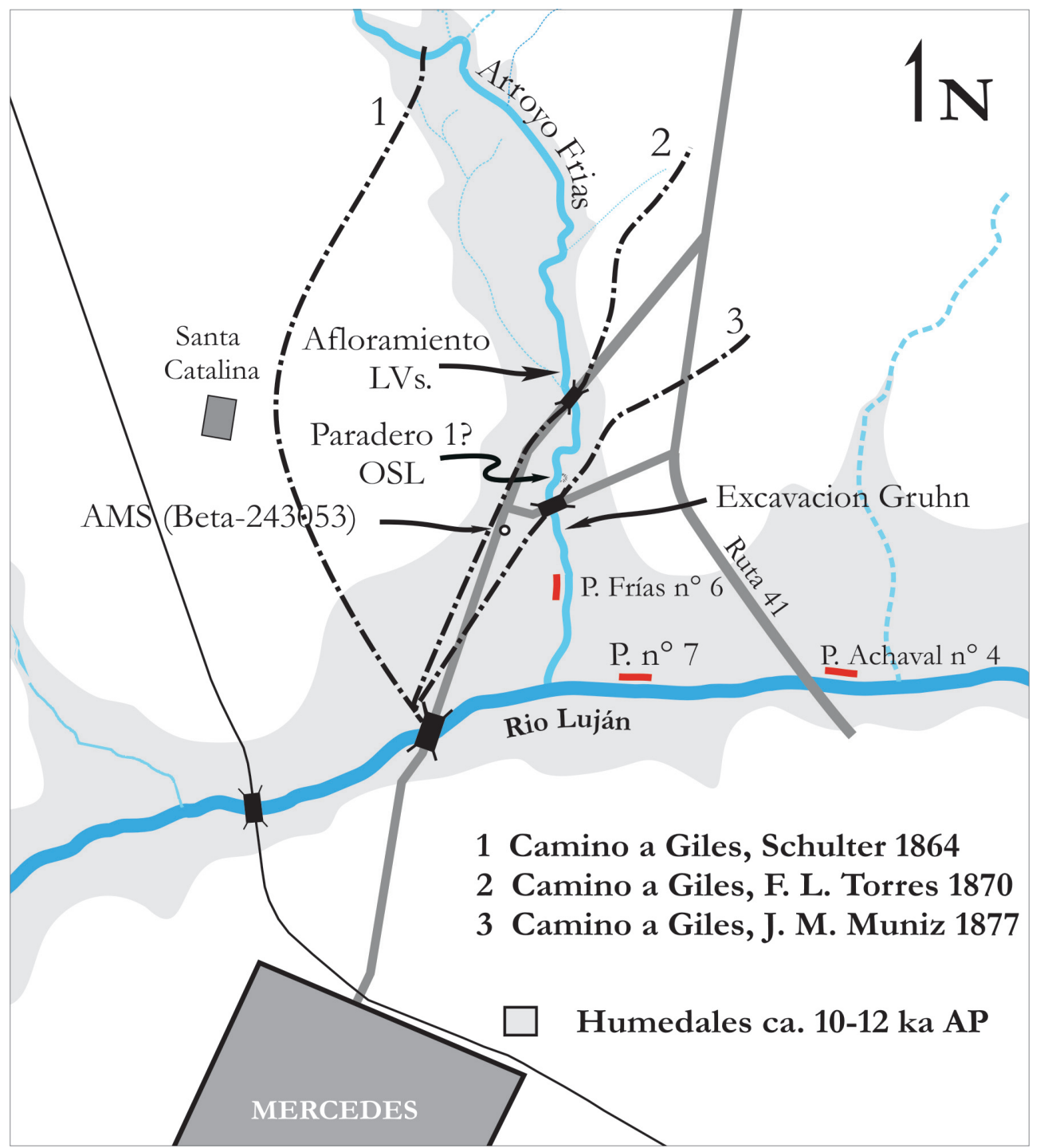

Fig. 3. Posición relativa de las sendas a Giles respecto a los puentes actuales, de la excavación hoy visible atribuida a Ameghino y posición de las muestras datadas respecto a la extensión de humedales (sombreado) hacia 10 -11 ka AP.

construido a fines de los años 1870's.

El arroyo Frías se llama actualmente Arroyo Grande y desemboca en la margen izquierda del río Luján casi enfrente de la ciudad de Mercedes (Fig. 1 y 3). El nombre de Frías, perdido hoy, proviene de los pobladores de estos campos a mediados del siglo XIX. Hacia 1870 los propietarios son los herederos de Pastor Frías con habitación principal en el casco de la actual estancia Santa Catalina. Las mensuras de 1864, 1870 y 1877 muestran cómo la posición del antiguo camino que unía las villas de Mercedes y de Giles se va desplazando hacia el este desde la vecindad de dicho casco en dirección a la desembocadura el arroyo Frías en el Luján. En efecto, hacia 1864 esta senda serpenteaba cerca de la población de Frías y seguía al norte para atravesar el arroyo a la altura de su primera bifurcación importante (Fig. 3). Luego este paso se desplaza hacia el sur, a las posiciones actuales. Hoy encontramos allí dos puentes vecinales y la georeferenciación de las antiguas mensuras, más el análisis de distancias allí asentadas, permite deducir que hacia 1870 existía un paso o vado en el punto del actual puente de cemento y posteriormente, hacia 1877 , se construye un puente, con casilla, probablemente de cobro de pontazgo, en la posición del 


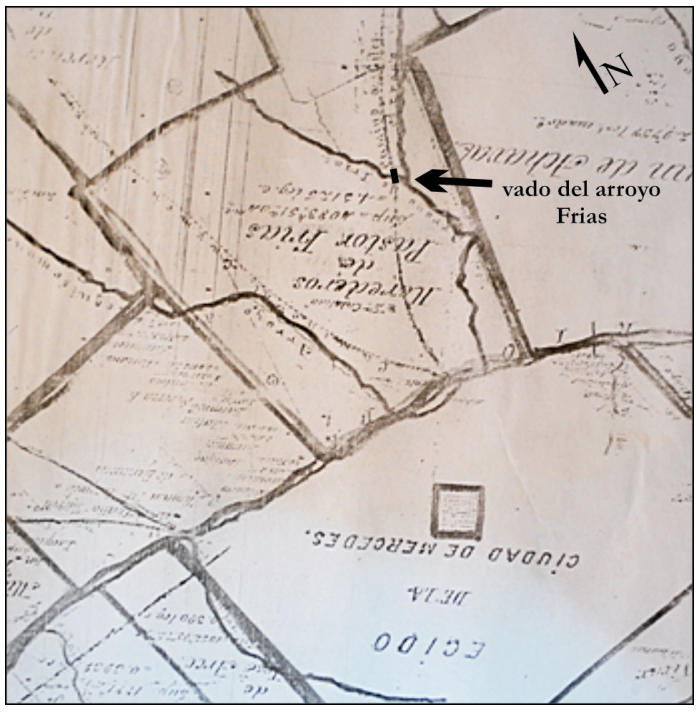

Fig. 4. Mensura de Schulter (1864). Nótese la posición del vado del caminoa la ciudad deGiles (Archivo deGeodesia)

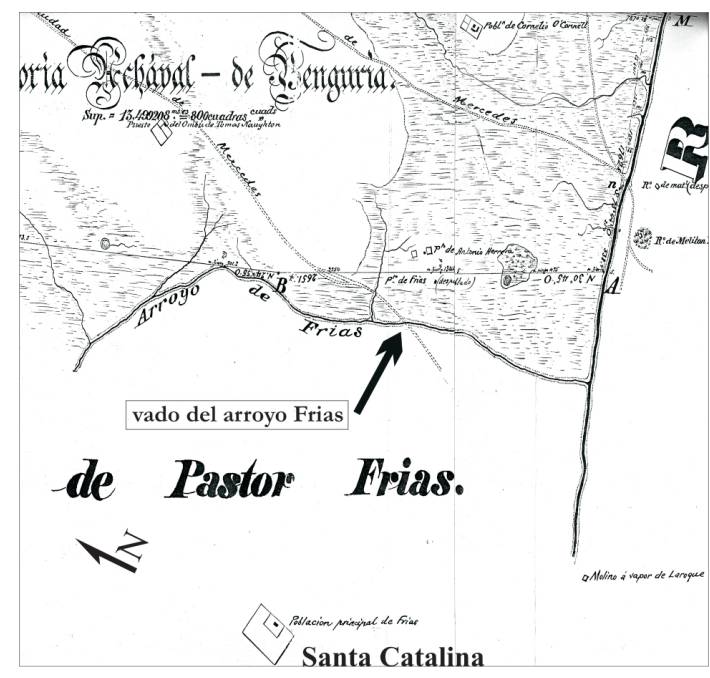

Fig. 5. Mensura realizada por Torres (1870) para la sucesión Achával de Benguria. Nótese la posición más al sur del vado del arroyo Frías (Archivo de Geodesia)

actual puente de hierro o "viejo" (Fig. 4, 5 y 6). Ello coincide con el hecho que Ameghino señala, hacia 1879/80, que la construcción del puente era muy "reciente".

En conclusión, el sitio de excavación debería encontrase en cercanías de este último punto, sobre la margen izquierda. Este puente correspondería con el dibujado por Mouhsen hacia 1940 desde la margen izquierda, vista hacia el norte (Mouhsen, com. pers. y C.A. Dagnino, 2014).

$\mathrm{El}$ análisis de las imágenes satelitales revelan

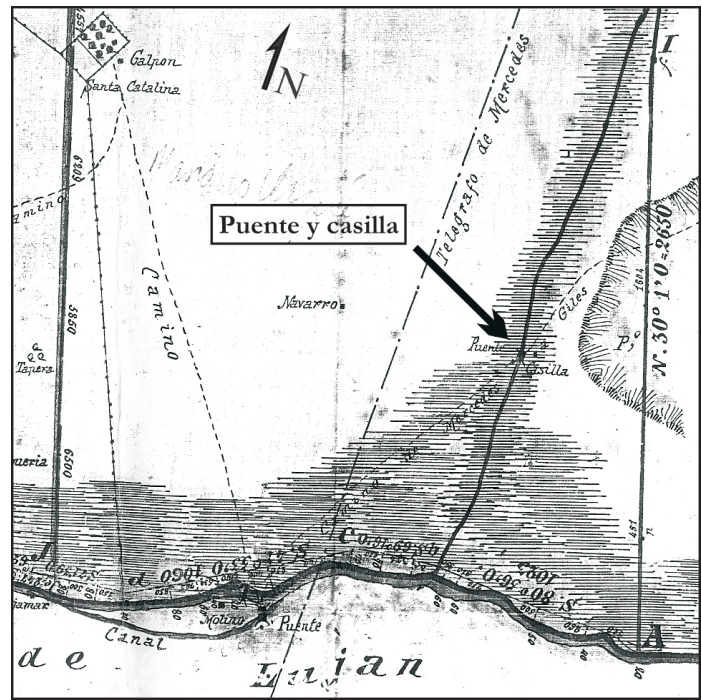

Fig. 6. Mensura de 1877 de José María Muñiz (nº 94 Archivo Histórico de Geodesia, La Plata) donde se observa un puente y casilla sobre el arroyo Frías, no existente en mensuras anteriores, correspondería al puente "nuevo" que menciona Ameghino al redactar su trabajo de 1879. El puente se habría construidos entre 1875 y 1877 (Archivo de Geodesia).

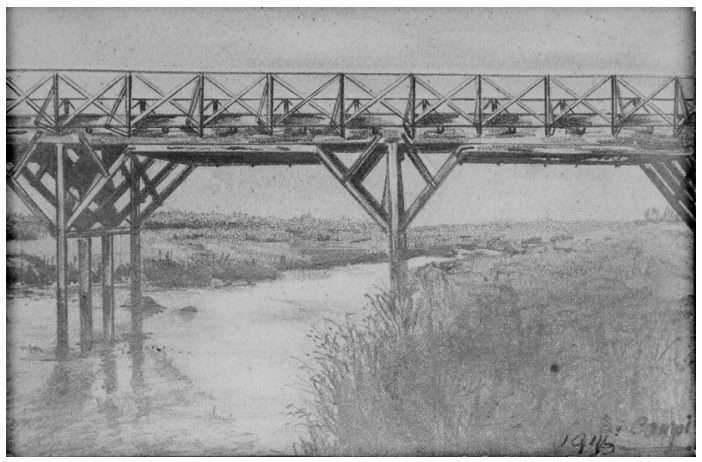

Fig. 7. Puente del arroyo Frías hacia 1940. Dibujo en lápiz de Campi de Mouhsen. Colección particular.

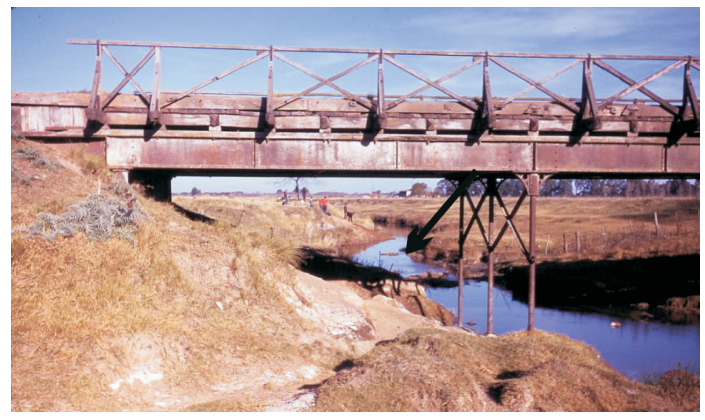

Fig. 8. El puente metálico en junio de 1970, (foto Ruth Gruhn) 




Fig. 9. Escotadura artificial en la barranca izquierda en

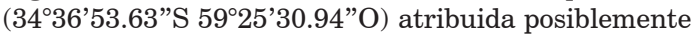
a la excavación de Ameghino por Orquera (1970).

una traza antigua de un camino dirigiéndose directamente desde el antiguo puente sobre el río Luján (Fig. 6) hasta el puente "viejo" de estructura metálica actual del arroyo Frías. La superposición del plano catastral de J.M. Muñiz (Fig. 6) coincide con dicho trazado relicto.

Ambos puentes se encuentran entre sí a una distancia de 650 metros y en este tramo, de la margen izquierda, la geología es similar consistente en loess y sedimentos loessoides rojizos de lateral de valle, bajo el manto de humus actual. Sólo aguas arriba del puente de cemento (puente "nuevo" o de la ruta a Giles, en la jerga local actual) la estratigrafía es menos monótona intercalándose los sedimentos verdosos de la Secuencia Luján Verde Superior (SLVs) (Toledo, 2011) y mantos negros asociados (Fig. 31).

Actualmente aún se observa una profunda escotadura artificial (Fig. 9) en la barranca izquierda del arroyo (34 $\left.36^{\prime} 53.50 » \mathrm{~S} 59^{\circ} 25^{\prime} 30.95 » \mathrm{O}\right)$, a unos 1300 metros de la desembocadura del río Luján y a 260 metros agua arriba del puente de hierro actual (Fig. 8). Correspondería probablemente a las excavaciones realizados por Ameghino en 1873. Orquera $(1970,1971)$ lo supone así al visitar el área y al realizar una trinchera en la margen opuesta. Esta escotadura sobre la barranca es sin duda una antigua excavación artificial ya que la topografía no revela allí la existencia de cárcavas afluentes naturales.

En el borde norte de la misma observamos, bajo el humus y aluvión actual, la acumulación del material extraído de la excavación, sepultando un lente de carbón vegetal interpretada como vestigios de un fogón de excavadores. Sin embargo el carbón fue datado por el método $A M S$-post bomb a partir del factor $F$ (Reimer et al., 2004), entre los años 1956 y 1957 (Tabla 1 y Fig. 10). Esto pone en evidencia intervenciones intencio-

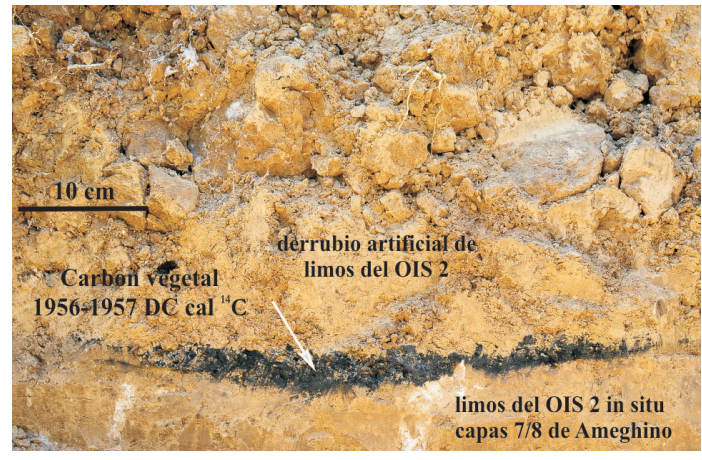

Fig. 10. Sección de restos de fogón sepultados por derrubio de excavación reciente (1950's) en la pared norte de la excavación de la Fig. 9.

nales posteriores con fines desconocidos, o la preparación de una bajada de ganado como se observa en las fotos de Orquera, o una re-exploración del sitio por "neo-ameghinistas" (sensu Toledo, 2009) o un origen de toda la excavación reciente y totalmente ajeno a las actividades de Ameghino.

\section{La carta a Paul Gervais. Primera publicación en Europa. Octubre 1875}

No sabemos si aconsejado por Ramorino o llevado por su tozudez pero, sin duda incentivado por su reciente nominación honorífica otorgada por la Sociedad Científica Argentina (SCA), Ameghino con solo 21 años, toma la pluma y desde el pueblo de Mercedes el 31 de Octubre de 1875 se dirige, en tímido francés, directamente al eminente Profesor Paul Gervais, entonces a cargo de la cátedra de Anatomía Comparada del Museo Nacional de Historia Natural de París. Casinos (2012: 66) es el único autor que se detiene en esta carta que la califica de "curiosa" en su objetivo y estilo.

¿Por qué escribe a Gervais y no algún otro "sabio" europeo? Más allá de algún consejo o recomendación que le pudiera sugerir Ramorino o algún integrante de la red francesa de coleccionistas, hay dos razones fundamentales que convierten a Gervais en un referente ideal: por un lado ya se había publicado el hallazgo de los primeros fósiles humanos argentinos llevados a Paris por Seguin, y por otro en las láminas de su obra sobre el hombre cuaternario aparecen restos óseos modificados como los que Ameghino encontraba en su Plioceno lujanense. Se observa también que de los textos de síntesis de la época es de los pocos o el único en que se da importancia y se ilustra la evidencia no lítica, es decir la 


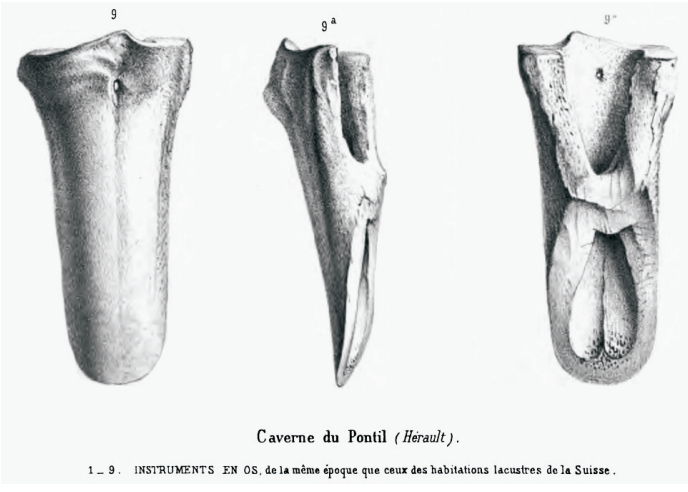

Fig. 11. Grabadon ${ }^{\circ} 9$ delaláminaII delaobra "Recherches sur l'ancienneté de l'homme et la péríode Quaternaire " (Gervais 1867) que Ameghino comparó con la pieza $\mathrm{N}^{\circ} 116$ de su colección pampeana enviada a la SCA.

de huesos "trabajados" con cortes y, sobre todo, fracturación intencional para extraer la medula ósea. Las explicaciones tafonómicas abundan en el tratado de Gervais y el listado de las "pruebas" de la existencia del hombre "cuaternario" europeo recuerda al listado que de las mismas hará Ameghino en su memoria de 1876 del hombre plioceno mercedino. Efectivamente, el primer párrafo de la carta revela que Ameghino había leído "Recherhces sur L'anciennete de L'Homme et la període Quaternaire" (Gervais, 1867). También ya había citado esta obra en su memoria "El hombre cuaternario de la Pampa", escrita a principios de 1876, al hacer referencia a un hueso con fractura antrópica similar a un ejemplar encontrado en el valle de Luján y que entrega a la Sociedad Científica Argentina (SCA) (Fig. 11). Si bien sus biógrafos citan a la obra de Lyell sobre el hombre fósil y su temprana influencia sobre Ameghino creemos, sin embargo, que para interpretar el contenido de sus paraderos fue más influyente la obra de Gervais donde se hace referencia explícita a piezas ósea modificadas resultantes de la extracción de la medula en los yacimientos de Europa, en particular la caverna de Bize, y ofrece para comparación una serie de grabados de alta calidad sobre material óseo y líticos (Fig. 11). La popular obra de divulgación de Figuier (1873), cuya significación es profundamente analizada por Blanckaert (1997), es citada por Ameghino, edición de 1870, en su trabajo sobre la Banda Oriental. Ameghino también reproduce en detalle los trabajos de Lartet (Ameghino 1870: 24) y Dupont (Ameghino, 1870: 143) respecto a la evidencia arqueológica y etnológica de extracción de medula a partir de los restos óseos fracturados y la presencia de rayas o estrías de corte.
Ameghino resume en su carta a Gervais los descubrimientos de Frías, da por hecho que está ante un "hombre fósil" y sin más le solicita que publique la noticia en su Journal. Gervais accede a su pedido y, los párrafos de la carta referidos a dicho descubrimiento y a otros sitios entre Luján y Mercedes, son publicados a fines de 1875 con un título que recuerda el precedente artículo de Gervais (1872) sobre el hallazgo de Seguin en el Carcarañá (Fig. 11). Estos últimos habían sido comunicados bajo el título "Debris humains [...]" y la nota de Frías fue publicada por Gervais bajo el de "Nouveaux debris de l'homme [...]". Así, a partir de un simple correo, Ameghino obtiene una publicación en un prestigioso Journal europeo donde describe claramente la supuesta asociación de restos humanos y fauna extinta. Según Ameghino (1881), hacia la misma época el profesor de la Universidad de Buenos Aires, Giovanni Ramorino (Fig. 12) preparaba un trabajo sobre los hallazgos de Frías para ser presentado a la SCA. Esta relación recuerda la inicial colaboración entre Tournal y de Serres en Francia sobre el anuncio de las primeras evidencias del hombre antediluviano. Queda la duda sobre si la comunicación al Journal de Zoologie fue concertada con Ramorino, con quien lo unían estrechos lazos, o si Ameghino actuó de forma independiente para "preservar" su prioridad frente al mismo, o a otros estudiosos. A pesar de los inicios auspiciosos para este descubrimiento, poco después, acontece un hecho que tendrá importantes repercusiones históricas e epistemológicas: el viaje de los comisionados por la Sociedad Científica Argentina. De este evento, que junto a Fernández (1982) consideramos un punto bisagra en la historia de la arqueología pampeana, nos ocuparemos en detalle más adelante. Antes vamos examinar el importante rol que cupo al profesor Ramorino en las investigaciones de Ameghino en las barrancas del río Luján.

\section{El profesor Giovanni Ramorino: el nexo con el hombre terciario europeo}

Para analizar el bagaje intelectual con el que Ramorino (Fig. 12) llega a la Argentina y su influencia directa sobre Ameghino hay que considerar previamente el estado del debate en Europa sobre de las pruebas materiales del hombre fósil cuaternario y terciario en la década de 1860 . El rol de Ramorino fue tan importante, como poco conocido, en impulsar las primeras actividades relacionadas con hallazgos de índole "prehistórica" en Luján y en mantener una estrecha rela- 
Tabla 1: Edades AMS y OSL para las capas 4, 5 y 9 de Ameghino 1881, Lam XXI. Edades AMS para nivel orgánico sobre secuencia Luján Verde Superior, ver figura 3a para la ubicación estratigráfica de las muestras.

\begin{tabular}{|c|c|c|c|c|c|c|c|c|}
\hline Localidad & Nivel & Código lab. & Método & $\begin{array}{l}\text { Material } \\
\text { datado }\end{array}$ & Edad & $\pm 1 \sigma$ & $\mathrm{C} 13 / \mathrm{C} 12$ & $\begin{array}{l}\text { C14 Cal. } \\
1 \sigma \mathrm{AP} / 1 \sigma \\
\text { OSL }\end{array}$ \\
\hline $\begin{array}{l}\text { Arroyo. Frías . } \\
\text { Mercedes } \\
34^{\circ} 37^{\prime} 3.11^{\prime \prime S} \\
59^{\circ} 25^{\prime} 39.00^{\prime} \mathrm{O}\end{array}$ & $\begin{array}{c}\text { Base « Platense Negro " } \\
(\mathrm{MN}) . \text { Capa } 5 \text { Amegh. }\end{array}$ & Beta-243053 & AMS & $\begin{array}{l}\text { materia orgáni- } \\
\text { ca sedimento. }\end{array}$ & 8210 & 50 & $-19.1 \%$ & $\begin{array}{c}9262- \\
9090 \\
\text { Calib } 5.1\end{array}$ \\
\hline $\begin{array}{l}\text { Arroyo Frías, } \\
\text { excav. Amegh.? } \\
34^{\circ} 36 \text { '53.12"S } \\
59^{\circ} 25^{\prime} 30.78^{\prime \prime O}\end{array}$ & $\begin{array}{l}\text { LR, nivel agua, } \\
\text { Paradero I } \\
\text { Capa } 9 \text { Amegh }\end{array}$ & $\mathrm{X} 2726$ & OSL & sedimento. & 32360 & 2150 & -- & $\begin{array}{l}34510- \\
30210\end{array}$ \\
\hline $\begin{array}{l}\text { Arroyo Frías, } \\
\text { excav. Amegh.? } \\
34^{\circ} 36 \text { '53.12"S } \\
59^{\circ} 25^{\prime} 30.78^{\prime} \mathrm{O}\end{array}$ & $\begin{array}{c}\text { Fogón bajo derrubio } \\
\text { borde norte excav. } \\
\text { Ameghino (?) }\end{array}$ & $\begin{array}{l}\text { AA98235 } \\
\text { FRMERC }\end{array}$ & AMS & carbón & $\begin{array}{l}(\mathrm{F}=1.0382) \\
\text { Post bomb }\end{array}$ & 0.0044 & $-26.9 \%$ & $\begin{array}{c}1956-1957 \\
\text { DC } \\
\text { Oxcal v4 } \\
1.7 \mathrm{SH}\end{array}$ \\
\hline $\begin{array}{l}\text { Arroyo Frías, } \\
\text { excav. Amegh.? } \\
34^{\circ} 36{ }^{\prime} 53.12^{\prime S} \\
59^{\circ} 25^{\prime} 30.78^{\prime \prime} \mathrm{O}\end{array}$ & $\begin{array}{c}\text { Base humus-transición } \\
\text { a Bt } \\
\text { Capa } 4 \text { Amegh. }\end{array}$ & $\begin{array}{l}\text { AA98241 } \\
\text { FRMERMN }\end{array}$ & AMS & $\begin{array}{l}\text { materia orgáni- } \\
\text { ca sedimento. }\end{array}$ & 2179 & 76 & $-17.2 \%$ & $\begin{array}{l}2074- \\
2314\end{array}$ \\
\hline $\begin{array}{l}\text { Arroyo. Frías . } \\
\text { Mercedes } \\
34^{\circ} 36^{\prime} 33.98^{\prime \prime} \mathrm{S} \\
59^{\circ} 25^{\prime} 33.27^{\prime} \mathrm{O}\end{array}$ & $\begin{array}{c}\text { Base nivel orgánico } \\
\text { sobre LVs. Puente ce- } \\
\text { mento }\end{array}$ & $\begin{array}{l}\text { AA98240 } \\
\text { FRLVSMN }\end{array}$ & AMS & $\begin{array}{l}\text { materia orgáni- } \\
\text { ca sedimento. }\end{array}$ & 5001 & 65 & $-17.1 \%$ & $\begin{array}{c}5653- \\
5884\end{array}$ \\
\hline
\end{tabular}

ción con Ameghino, sin duda facilitada por el origen ligur de ambos (Ameghino, 1881; Camacho, 1971; Fernández, 1982). ¿Cuál había sido el rol de Ramorino en los estudios prehistóricos italianos y en qué estado estaban el conocimiento y discusiones sobre el hombre fósil en vísperas de su partida a Buenos Aires?

Ramorino nació en Génova en 1840, se doctoró en ciencias en la Real Universidad de esta ciudad y renunció a su posición de asistente en el Museo de Historia Natural para trasladarse a Buenos Aires en 1866. Abandona Europa en pleno debate del "hombre terciario", luego de aceptar el cargo de profesor de ciencias naturales en la Universidad de Buenos Aires en remplazo de otro compatriota suyo, Pellegrino Strobel, quien había renunciado sorpresivamente a su cargo de profesor en abril de 1866. Ramorino trae un bagaje muy particular: un conocimiento profundo del estado del debate sobre el hombre "diluviano" y "antediluviano" y su pasión por la geología, arqueología y antropología. Se debe destacar que le eran muy familiares los conceptos, principalmente de orden tafonómico, que utilizará Ameghino en el Valle del Luján como pruebas de la acción humana: las marcas de corte e impacto sobre huesos de fauna extinta, más la obvia la asociación con artefactos líticos. Otras obser- vaciones incluían el hecho de estar estos restos óseos más o menos rodados y articulados o no. Un aspecto no menos importante es la inclinación de Ramorino a aceptar hallazgos en capas pliocénicas y post-pliocénicas, considerando dignas de estudio también los provenientes del Mioceno. Así, el debate europeo del "hombre terciario" llega de forma insospechada a Luján de la mano de uno de sus protagonistas. Sin duda esto predispuso al joven Ameghino, en edad de ser discípulo de Ramorino, a explorar los ríos bonaerenses sin prejuicios sobre la antigüedad de los hallazgos. Ramorino, que había iniciado sus cursos en la universidad de Buenos Aires en 1867, en 1868 es también nombrado profesor en el Colegio Nacional de Buenos Aires, abandona la Argentina en 1876 luego de pedir licencia en la Universidad por una grave enfermedad, y fallece a poco tiempo de llegar a Génova. Durante ocho años Ramorino alternó su actividad docente con viajes de campo en la provincia de Buenos Aires tras los temas de su predilección, la mineralogía, la geología, y la arqueología. Así es que escribe un ensayo inédito sobre la "piedra movediza" de Tandil y en 1869 publica "Rudimentos de Mineralogía" constituyendo el primer texto de historia natural publicado en la Argentina (Camacho, 1971). Es miembro de la Sociedad 


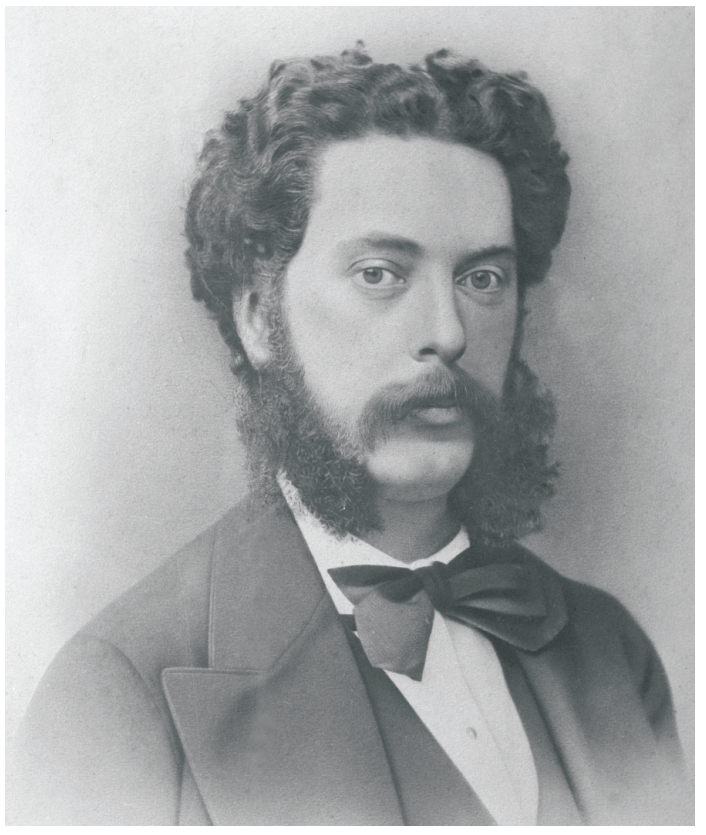

Fig. 12. Prof. Giovanni Ramorino (Cuadro del Departamento de Geología, FCEN-UBA).

Científica Argentina y su presencia en el seno de la colectividad italiana fue muy importante ya que fuera uno de los fundadores del Círculo Italiano. No hay datos concretos pero quizás Ameghino conoció a Ramorino en sus estadías en Buenos Aires o como alumno de la escuela normal de preceptores en 1870 , aunque un primer contacto pudo haberse producido en Luján en 1869 durante la extracción de un gliptodonte junto a material lítico en Luján.

¿Cuál era la experiencia de Ramorino en temas arqueológicos? Arthuro Issel (1860) describió en el Annuarío Scientifico Italiano (en De Mortillet, 1866:186) el descubrimiento fortuito de una cavidad cárstica durante los trabajos de construcción del ferrocarril en la comuna de Verezzi. La cavidad fue explorada por Ramorino, por encargo de la Academia de Turín, quien encuentró debajo de una plancha carbonática, limos rojizos con abundante fauna compuesta por équidos, bóvidos, cérvidos y conchillas marinas. Issel (1864) se ocupó de la determinación del material malacológico y designará una nueva especie, Helix ramoriniana Iss. en honor a Ramorino. De Mortillet (1866) resumió las evidencias del hombre según el artículo de Issel, de ese modo la presencia de marcas de corte y huesos fracturados deviene un leiv motif de las discusiones sobre la presencia humana en los dominios de la geología: “...cette dernier coquille (Mytilus edulis) étant marine n'as pu se trouver la que par la suite de l'intervention de l'Homme. L'existence de l'Homme est encore prouvé par la présence des fragments de charbon Dans la terre rouge; par des os long casses pour avoir la moelle par d'outre os présentant des entailles et des incisions qui semblaient faites avec des grossières instruments taillants, il ya même des os qu'on dirait scies...".

Ramorino piensa que el yacimiento es contemporáneo o tal vez posterior a la breche de Nice estudiada por Cuvier y prepara una memoria detallada para la Academia de Turín. Issel (1875) reportó también haber visitado otra caverna más moderna con Ramorino. De todo ello se desprende la existencia de una estrecha colaboración con Issel y el grado de conocimiento que se tenía de sus investigaciones en el medio de los círculos dedicados a los estudios "antehistóricos" italianos y franceses.

¿Cómo Ramorino se interesa por las marcas de corte? En 1863, Denoyers observando restos provenientes del valle del Arno depositados en París descubre marcas de corte lo que lo lleva a admitir la existencia del hombre terciario también en Italia (Denoyers, 1863). Ramorino influenciado por el anuncio de Denoyers, revisó las colecciones de la misma proveniencia que se encontraban a su cargo en el museo de Historia Natural de Génova y en un cúbito de rinoceronte cree ver marcas de corte realizadas por bordes de instrumentos líticos cuando el hueso estaba aún en estado fresco (Ramorino, 1866; Issel, 1875).

Ramorino presentó sus conclusiones en la histórica reunión de la Spezia donde reportó los restos óseos del Plioceno de Toscana 'il cuali presenta curíosi indice di esser state qua e la incise dalla mano dell'uomo" y explicó los motivos por los cuales creía que tales incisiones son contemporáneas a la época en que vivían dichos mamíferos. Allí, Issel (1875) tuvo la oportunidad de examinar este material y coincide con Ramorino sobre el origen antrópico de las marcas.

Es así, que en vísperas de su partida a Buenos Aires Ramorino había estado en el centro de los debates sobre el hombre fósil y particularmente en el de las evidencias tafonómicas. El año siguiente envía una comunicación a la Academia de Ciencias de Turín titulada "Sopra le caverne de Liguria, e pricipalmente sopra una recentemente scoperta a Verezzi". Ramorino detalla en particular los materiales recuperados en la cueva Verezzi 


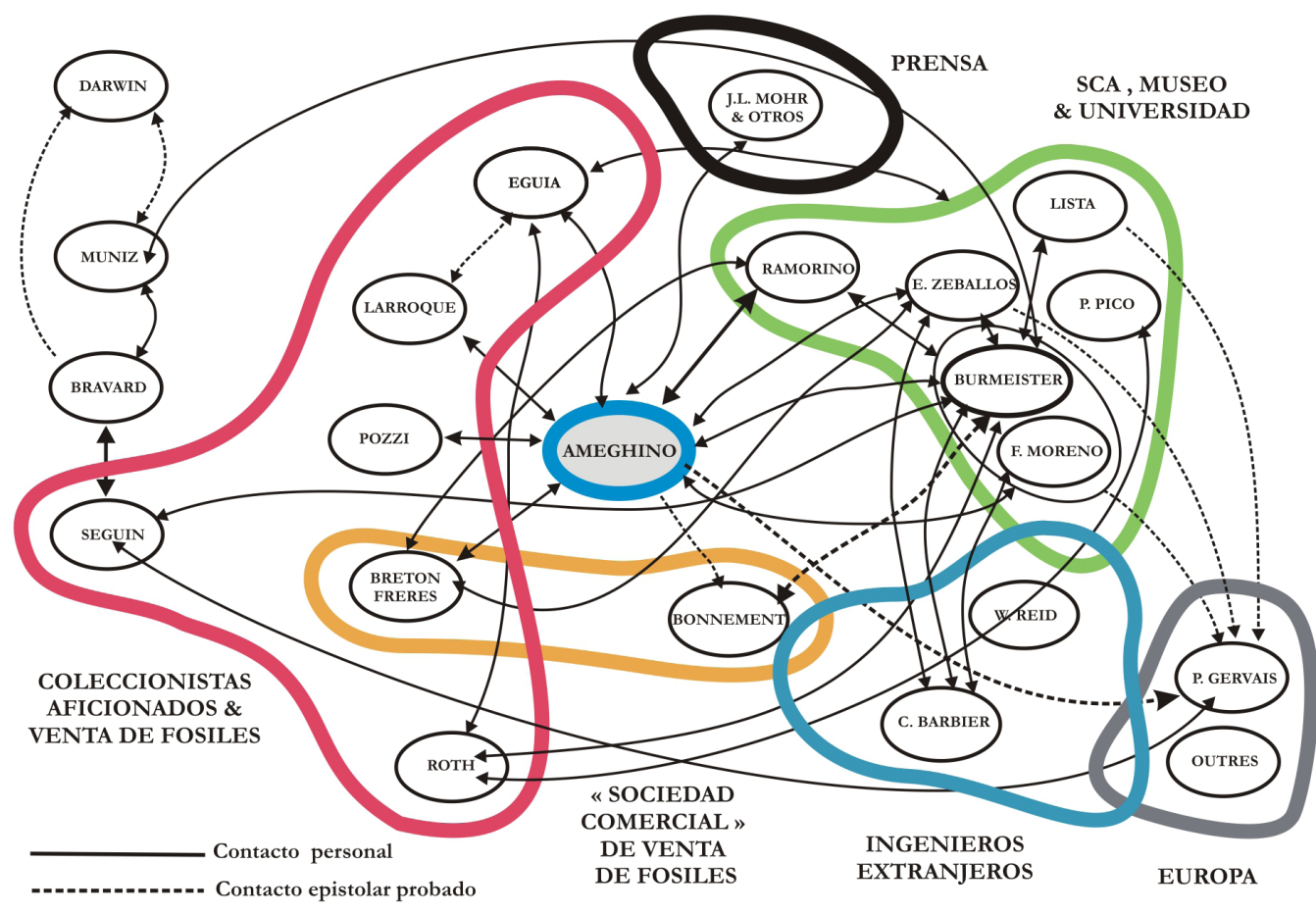

a

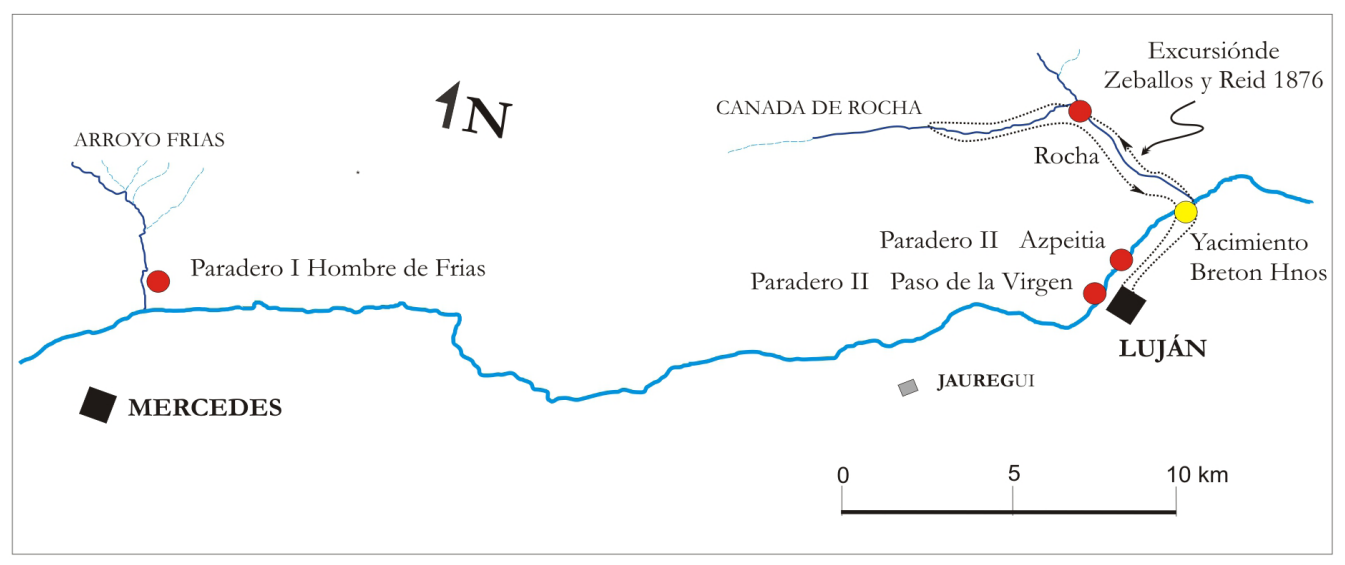

Fig. 13. A Esquema de redes y nodos relacionados con Ameghino en el periodo de estudio. B Itinerario aproximado de la excursión de Zeballos y Reid en 1876 en el arroyo Marcos Díaz-Cañada de Rocha respecto a los sitios de Luján y del arroyo Frías de Ameghino (1881).

donde deduce la presencia humana por restos de carbón y huesos calcinados y fauna similar a los hallazgos de la localidad de Finale (Issel, 1864). Se destaca la presentación de Ramorino como un estudio cuidadoso y con criterio y así obtiene una nueva subvención para el año 1866. Por otro lado, las investigaciones de Ramorino no quedaron invisibles en reportes de congresos o revistas provinciales sino que fueron integradas a la bibliografía de síntesis sobre el origen del hombre como por ejemplo la "Paleontología Humana" de Hamy (1870), quien luego de describir las dudas de Lyell sobre las estrías de los huesos del Arno, refiere:

"M. le professeur Giovanni Ramorino c'est montre moins timide (que Lyell n.a.) 


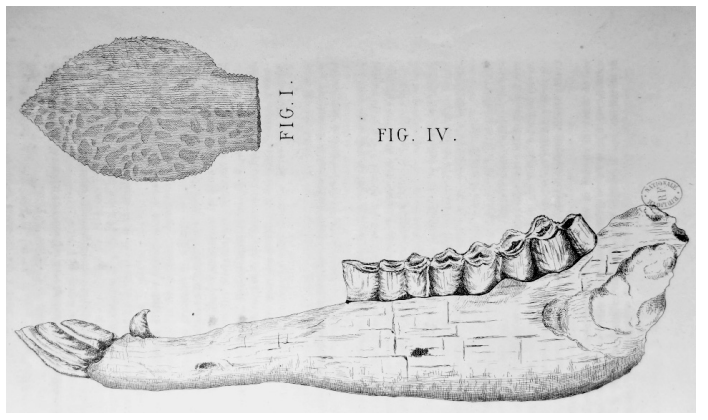

Fig. 14. Dibujo de la "punta de flecha" supuestamente extraída por los hermanos Bretón, inserta en un cráneo de Smilodon y maxilar inferior de Lama guanicoe recolectada por Zeballos y Reid en su excursión por la Cañada de Rocha-Arroyo Marcos Díaz

\begin{abstract}
en présence de témoignages du même ordre qu'il avait recueilli au musée de Genès, en 1865. La communication de ce savant paléontologiste a la réunion extraordinaire la société italienne des sciences naturelles a la Spezzia est d'autant plus intéressante, que le pièces qu'il a présentés montrent a cote des traces produites par al main humane, celles que peuvent expliquer, en dehors de la action de l'homme, les incisions des ossements pliocènes » (Hamy $1870: 101-102$ ).
\end{abstract}

Lubock también lo cita en su obra "Homme prehistorique" (Lubock, 1976:382) así como también Issel en su "L'uomo prehistórico in Italia" (Issel, 1875:738). Todos estos descubrimientos suscitan controversias centradas en los aspectos geológicos y en la autenticidad de las evidencias de acción humana. Proveniencia estratigráfica y criterios de reconocimiento de marcas vuelven una y otra vez a la escena. Hay que destacar que en los casos de St Prest y Val d'Arno, entre otros, la presencia humana no es inferida por la asociación con instrumentos líticos, sino por la acción de los mismos durante operaciones de descarne. Esta acción queda registrada en las incisiones y estrías de corte sobre la superficie de los huesos de animales despostados. Pero ¿cómo se diferenciaba de un accidente natural?, ¿qué criterios permitían adjudicarlas al hombre?. Estos interrogantes repercuten en el Plata, pero la influencia sobre Ameghino de estos debates, canalizada por Ramorino, y las lecturas de las Recherches de Gervais es olvidada o ignorada por casi todos sus biógrafos. Queda entonces, a partir de las reseñas hagiográficas de éstos, solo la imagen épica de un Ameghino joven, autodidacta, explorando solo, sin descanso

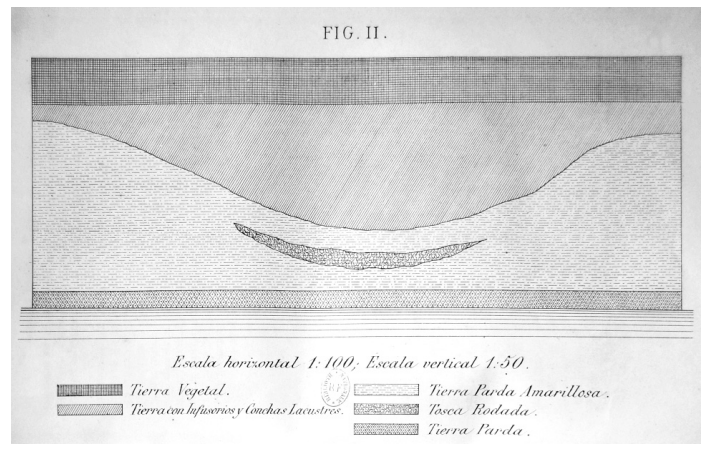

Fig. 15. Corte de la barranca del río Luján y la desembocadura del Arroyo Marcos Díaz (Zeballos y Reid, 1876).

y en contra del stablishement científico porteño, los arroyos y barrancos entre Luján y Mercedes.

\section{La excursión verificadora de la SCA}

El 18 de marzo de 1876 Estanislao Zeballos acompañado por Walter Reid (ambos comisionados por la SCA), visitaron expeditivamente la desembocadura del arroyo Marcos Díaz (hoy arroyo del Haras) y su continuación en la Cañada de Rocha (Fig. 13) luego de que esta Sociedad recibiera el pedido de financiamiento de los hermanos Pedro y Juan Bretón para continuar extrayendo fósiles. Pedro Bretón en sociedad con Bonemment había tenido permiso de prospección en 1864 a cuentas del Museo Público y, abusándose del contrato, en 1872 propusieron su colección en venta a Germán Burmeister (Toledo, 2009:65).

La SCA niega el apoyo económico a estos hermanos, pero ante la noticia de ricos "yacimientos fosilíferos" y con el objetivo principal de verificar el hallazgo de una punta lítica incrustada en un cráneo de Smilodon, la comisión directiva aprueba una visita de comisionados al río Luján. Zeballos y Reid no contactaron a Ameghino, y supusieron erróneamente, estar explorando los sitios "pliocenos" de este último. Tampoco quedaron satisfechos con los hermanos Bretón ya que a pesar de excavar varias horas no encontraron ningún resto y la actitud de los mimos era "sospechosa". En junio, publican los magros resultados de su excursión en los Anales de la SCA (Zeballos y Reid, 1876), con un grabado del lítico (Fig. 14), que fue considerada por Toledo, (2005:422; 2009: 86) tal vez la primer punta tipo Cola de Pescado o Fell ilustrada para el área pampeana aunque recientemente Nami $(2014,2012)$ se atribuyó esta interpretación; restos de guanaco (Fig. 14) 


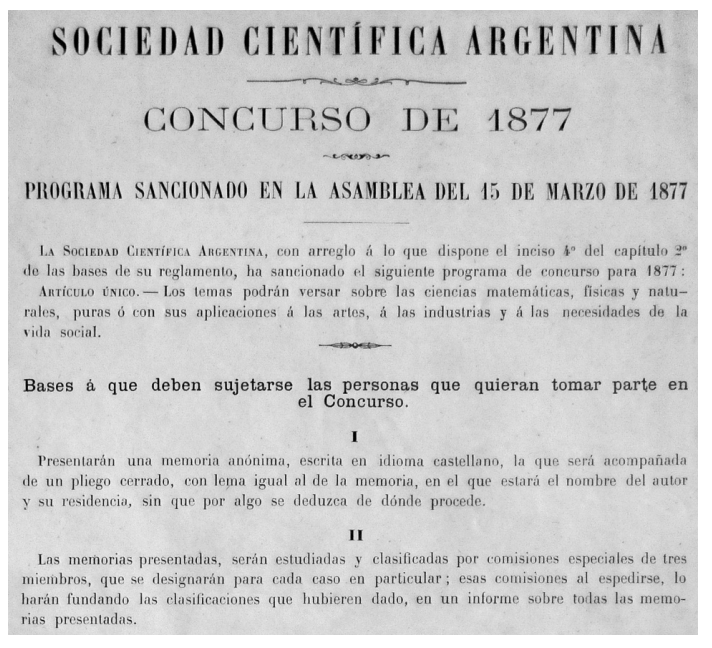

Fig. 16. Llamado a concurso de la SCA para el año 1877. Se eliminaron de la ilustración la lista de condiciones del concurso. (Archivo Zeballos)

y un corte estratigráfico de la desembocadura del arroyo Marcos Díaz (Fig. 15).

Con la incómoda experiencia de esta infructuosa incursión al campo, más la descripción del sitio de "Cañada de Rocha" que Ameghino había publicado en La Nación en enero de 1876, y el manuscrito de "El hombre cuaternario de la Pampa" enviado por Ameghino a la SCA en abril, Zeballos, en calidad de Secretario de dicha sociedad, informó a la comisión directiva que Ameghino:

\section{"habiaincurridoenunerrorfundamental atribuyendo una edad remotísima a objetos que apenas tendrían tres o cuatro siglos y declaraba fósil lo que es contemporáneo de los aluviones modernos".}

Esta última conclusión constituye un punto bisagra en la historia de la arqueología argentina ya que tempranamente condenará al olvido todas las evidencias de la coexistencia del hombre y la fauna extinguida, profusamente documentadas por Ameghino, a lo largo del valle del río Luján. Ese evento, como la cuestión tafonómica, pasó desapercibido para la gran mayoría de los historiadores de la ciencia y biógrafos. Esto ocurrió posiblemente por el desconocimiento de la geografía y toponimia local, la falta de reconocimiento de campo y, fundamentalmente, por la falta de datos comparativos entre la estratigrafía de los sitios de Ameghino y los del área de Cañada de Rocha.

La parsimonia y renuencia de la SCA a dar curso a las monografías que Ameghino enviara espontáneamente y formalmente a los concursos científicos en 1876 (Fig. 16), con enfáticas y apasionadas descripciones de sus hallazgos, se explican no solo por el inadecuado y fallido control de campo de Zeballos y Reid, sino por un factor político subyacente: esta institución había otorgado un premio a Ameghino en 1875 y veía su reputación en juego si las nuevas afirmaciones del laureado terminaban siendo falsas $\left(36^{\mathrm{a}}\right.$ sesión del 15 de junio de 1876, Anales de la SCA, Tomo II, en Ameghino 1881:309 ).

En los informes internos y resoluciones de la SCA se observa que el rechazo no está fundado en argumentos técnicos sino en la valorización del autor como poco idóneo y en una posición de inseguridad, de duda y de lealtad soslayada a las ideas de Burmeister condensadas en la siempre defendible idea de prudencia científica (ver también Stagnaro 1993). Los fallos de esta sociedad se asemejan llamativamente a los emitidos en los períodos previos a la aceptación del "hombre fósil" en Europa veinte años atrás. Así por ejemplo en Francia Alfred Maury, profesor en el Collegue de France, aconseja a los anticuarios lanzados a la búsqueda del hombre fósil en las cavernas de Francia:

«Ne nous attons pas de conclure....Une pareille découverte d'homme fossile serait d'une grande importance, toute fois dans l'état actuel de nos connaissances elle ne semble pas probable, aussi est-il bon de se tenir en garde contre les conclusions précipitées tirées de quelques faits isolées " (en Laming-Emperaire 1964 :152)

Ameghino queda indignado del informe de Zeballos y Reid de junio y la resolución de la SCA respecto a la memoria "El hombre cuaternario en la Pampa" (presentada espontáneamente por Ameghino al partir a Europa Ramorino) y en agosto de 1876, presenta nuevamente su manuscrito rechazado, respaldándose en el hecho que el área de sus investigaciones no correspondía con la inspeccionada por Zeballos y Reid, sino que al contrario ésta se encontraba a solo 700 metros de la plaza de Luján y no a 7 kilómetros aguas abajo (Ameghino 1881:400-403). Como en su resolución la SCA declaraba quedar a la espera de más datos y pruebas materiales, Ameghino adjuntó a la memoria rechazada, la crítica aclaratoria al reporte de Zeballos y Reid más una colección de 116 piezas arqueológicas, incluidos los restos del hombre fósil de Mercedes. En la nota que acompaña la nueva presentación, critica lo 
expeditivo de la excursión, la ineptitud de los hermanos Bretón para cavar cuidadosamente, y junto a las nuevas pruebas (restos óseos modificados y líticos), envía un corte geológico de las barrancas del río Luján (quinta Azpeitia). Todo el terreno ganado con aquella mención honorífica de 1875 en el Nacional, es perdido y aún Zeballos (Fig. 17), co-fundador de la SCA, parece tomar distancia. Nuevamente, invita sin éxito a quien quiera ver, tocar y encontrar, a verificar en el campo sus afirmaciones con la esperanza que la comisión repita a la manera de Cesar "fuimos, vimos y... creímos!" (Ameghino 1881:401-403). Según Ameghino "varias personas" ya habían visitado el yacimiento y aceptado las pruebas in situ, pero no menciona quienes fueron a excepción de Ramorino. Ameghino deseaba y sabía que necesitaba el reconocimiento institucional de la Universidad, de la SCA y por extensión del Museo Público, pero a este último no podía recurrir mientras Burmeister siguiera allí o cambiara radicalmente de opinión.

La comisión directiva de la SCA y su secretario no deben haber recibido de buen agrado esta nueva avalancha de vehemencia señalando por un lado el error de los comisionados y por otro, obligándolos a la revisión de un cajón con objetos más la desafiante invitación a una salida de campo. Esta nueva presentación quedará sin resolución y dos años después Ameghino se ve obligado a reclamar la colección en vistas de su viaje a Paris. La comisión prefirió el silencio. Años más tarde, hacia 1910, con Ameghino ya célebre, Zeballos dió su versión de los hechos liberándose sutilmente de toda responsabilidad y culpando abiertamente a Moreno y su lealtad a Burmeister. Sin embargo, en distintas publicaciones de la época podemos constatar que Zeballos compartía las ideas y confusiones de Moreno respecto a estos sitios. Hacia diciembre de 1876 Zeballos había redactado hasta el capítulo VI de una obra inédita, El Hombre Primitivo de la provincia de Buenos Aires, pero solo publicará este capítulo en 1879 y allí revela cuál era su pensamiento real sobre el hallazgo de Frías:

\footnotetext{
"Loshuesoshumanoshalladosen Buenos Aires y atribuidos al período prehistórico, carecen de autenticidad, no a las personas que lo levantaron, sino a su situación. [...] aquellas falanges han ido arrastradas por las aguas a las orillas y playas en que fueron descubiertas. [...]No se dirá que son despojos de las guerras contemporáneas con los indios o de las lucha civiles que
}

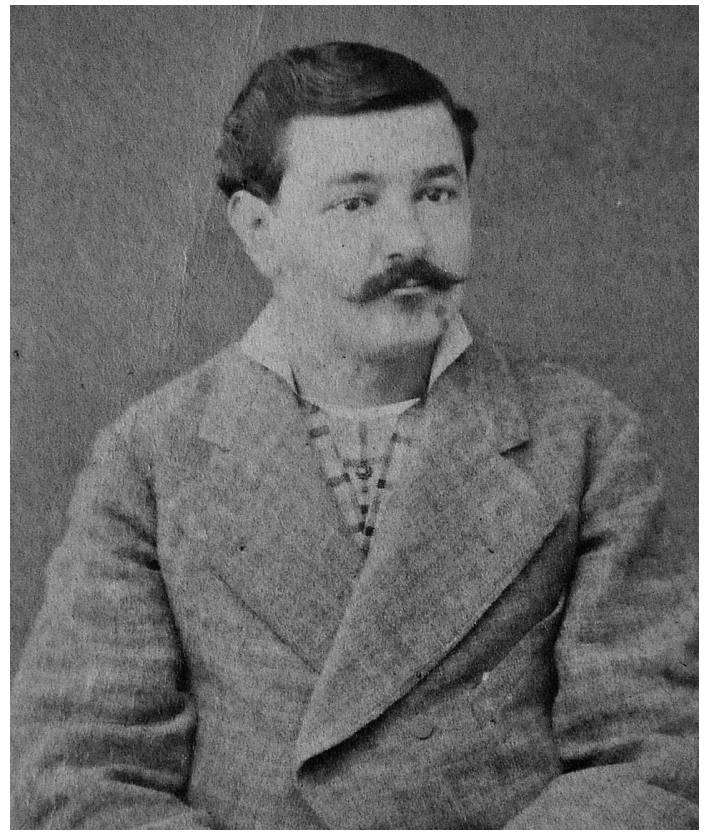

Fig; 17. Estanislao Severo Zeballos (1854-1923) en los primeros años de la década de 1870 (AyBEZ).

han sembrado millares de cadáveres en la pampa? (Zeballos 1879:47).

Este manuscrito nunca fue publicado completo a pesar de los pedidos de Gutiérrez y las insinuaciones de Quesada. Zeballos declaró en 1910 haber regalado el manuscrito más el atlas de ilustraciones a Ambrosetti. El Hombre Primitivo de la provincia de Buenos Aires incluia el primer mapa de sitios arqueológicos de la provincia (Fig. 18), permanecerá inédita a excepción del capítulo VI y cuya temática Zeballos retomará tardíamente en 1910. Hallamos en Archivo Zeballos de Luján (AyBEZ) el manuscrito inédito mecanografiado de la obra en un estado bastante avanzado. Las citas bibliográficas y el borrador de una carta a Ameghino del 3 de enero de 1910 pidiéndole datos para este trabajo, que Ameghino contesta el 5, revelan que Zeballos nunca abandonó la idea de escribir una obra extensa sobre el "hombre fósil" pampeano.

Se debe señalar que mientras Ameghino presentaba a la SCA en el curso de 1876 monografías repletas de información inédita ("El hombre cuaternario de la Pampa" y "Ensayos de un estudio de los terrenos de transporte de la cuenca del Plata"), que eran leídas, demoradas y rechazadas por Moreno, Zeballos y Pico, es decir por la SCA misma, este último redactaba un libro des- 
de principios del mismo año (Ameghino, 1881) titulado "Estudio geológico de la provincia de Buenos Aires, primer premio del concurso de la SCA de 1876, que se publicará en enero de 1877. Zeballos difundió esta obra en todos los medios a su alcance. Encontramos avisos de venta en varíos números de La Prensa, en intercambios epistolares envía un ejemplar al ingeniero Charles Barbier quien promete difundirla en Francia y en la Biblioteca Nacional de este mismo país; la encontramos incluida en un compendio de sus obras que envía para la Exposición Universal de 1878. Si bien las presentaciones a los concursos debían ser anónimas no habría sido difícil suponer para los evaluadores quién era el autor de las monografías de geología de la provincia en un círculo tan pequeño de personas interesados por ella. El estilo insistente y desafiante, e incluso la caligrafía de Ameghino, eran inconfundibles. En el seno mismo de la SCA la modalidad de elección de temas para concursos y conferencias llega a incomodar al socio Dr. Puiggiari quien denuncia que la comisión directiva los elegía con un proceder "hiriente", para beneficiar a ciertos socios. (SCA, 1876:227). Además de la nota sobre el hombre enviada espontáneamente a su nombre, Ameghino se presentó anónimamente al concurso de la SCA de 1876 pero su trabajo sobre los terrenos de transporte, nuevamente insistiendo sobre el hombre del Plioceno, es rechazada con duros conceptos a expensas de la presentación de Zeballos, laureado con el primer premio. En este trabajo se evidencia, nuevamente, que Zeballos confundió el paraje de Rocha, cercano a Luján, con el arroyo Frías, cercano a Mercedes y distante más de 30 kilómetros al oeste, y también confundió la comunicación enviada por Ameghino a Gervais sobre el arroyo Frías, como referente a la Cañada de Rocha. Zeballos revisa estos eventos en su manuscrito de 1910 y expone su versión de los hechos culpando abiertamente a Moreno de obstaculizar a Ameghino en el seno de la SCA no solo por su opinión contraria sino también por lealtad a Burmeister. Llamará a ambos los "jefes de la escuela argentina" a quienes no podía contradecir. Dado el prestigio que Ameghino fue adquiriendo con el tiempo, la muerte de Burmeister y su distanciamiento de Moreno, sin duda llevó a Zeballos a atenuar al máximo posible su parte de responsabilidad en los rechazos a las notas de Ameghino. Como bien señala Ameghino (1881:404), la confusión era de hecho imposible, pues, cuando envía su carta a Paul Gervais en octubre de 1875 aún no había descubierto el paradero de Rocha, hallazgo que

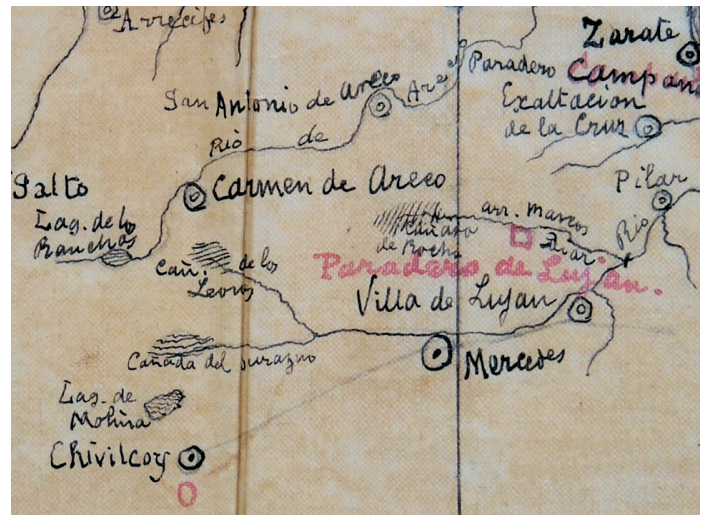

Fig. 18. Sector del valle de Luján extraído del mapa inédito de sitios arqueológicos que Zeballos preparaba hacia 1876 para su obra "El hombre prehistórico de la Provincia de Buenos Aires" (AyBEZ). Notar que llama "Paradero de Luján" al "paradero de Rocha" y no señala ni el arroyo Frías ni el sitio de hallazgo del hombre "fósil".

realiza recién en diciembre del mismo año acompañado por sus hermanos, Juan y Carlos. A lo largo de 1876 Ameghino buscó la legitimación de la SCA de sus descubrimientos e ideas frontalmente, con un lenguaje claro directo y sinceramente naif, confiado en el valor moral y científico de las pruebas materiales con resultados no solo nulos sino contrarios. Procesos similares ya habían ocurrido a fines del siglo XVIII y primera mitad del siglo siguiente entre coleccionistas, anticuarios y amateurs éclairés de provincia y las instituciones académicas centrales de Londres y Paris. La necesidad de aceptación y reconocimiento del naturalista o coleccionista local y la existencia de un entramado de diversos circuitos relacionales es analizada por diversos autores como Stagnaro (1994), Richard (2008:128) y Podgorny (2008:134), si bien en el caso de Lujan y Mercedes la certificación fue fallida y sin la guía del interesado. Luján no se transformaría nunca en la Abbeville pampeana. Si comparamos estos eventos con el proceso de aceptación de existencia del hombre en capas "diluvianas" junto a fauna extinta en Europa, en particular por la Academia de Francia, surge que las comisiones de certificación se crean y desplazan al valle de la Somme solo ante una presión externa, insoslayable: los geólogos y paleontólogos ingleses ya habían aceptado dicha coexistencia y habían realizado también viajes de verificación en territorio francés, donde hacía décadas, sin éxito, Boucher des Perthes declaraba, denunciaba y publicaba la presencia de "antiquites antediliviennes" junto a 
fauna extinta. Frente a estos hechos inocultables los círculos oficiales enviaron verificadores como Gaudry y Pouchet quienes precipitadamente se apropiaron de las ideas y hallazgos de Boucher de Perthes (Groenen, 1994:68). Sin embargo, encontramos que la situación entre Ameghino y la SCA es muy similar a la ocurrida entre 1827 y 1833 entre Tournal, los círculos provinciales y la "hegemonía parisina" del Institut (Guilaine y Alibert, 2016). Tournal fue quien reconoció por primera vez hacia 1827 , también con solo 22 años, la coexistencia del hombre con fauna extinta en las brechas osíferas de Bize (Aurel, 2009; Rudwick, 2008). Rápidamente abrazó el transformismo y reconoció la importancia de la geología para comprender los terrenos de transporte "antediluvianos". Trató de convencer sin éxito a Cuvier, fue apoyado en parte y trabajó con de Serres, fue contrariado por Destrem y sus notas fueron recibidas por Cordier quien actuó como moderador y fue parte de la comisión en la Academie des Sciences para estudiar el problema junto a Brogniart y Cuvier. Así, podemos hacer un paralelo con los roles de Burmeister, Ramorino, Lista/Moreno y Zeballos respectivamente. Tournal escribe en medios locales, presenta notas a la Academia, envía pruebas materiales al Museum, e insiste en ser visitado en el terreno. Paris se refugia, como lo hará la SCA, también en una prudencia forzada, en el rigor científico y en comisiones diletantes.

Con sus monografías rechazadas o ignoradas y Ramorino ausente, la situación parece haber llegado a un punto de no retorno para Ameghino quien solo, confronta a los príncipes de la ciencia porteña, cuando aparece un nuevo personaje en escena: Ramón Lista. Lista es un joven sin mayor experiencia, amante de las ciencias naturales, cercano al círculo de Burmeister, quien, sorprendentemente, se considera con autoridad y derecho a publicar sus opiniones sobre la cuestión del hombre fósil. Y con mucha pretensión, publicó un artículo en La Tribuna, y también envió una nota al Journal de Zoologie de Gervais donde defiende sin reparos, pero sin elementos propios la posición de Moreno y Zeballos.

Sin embargo, en el cuaderno copiador epistolar de este último (AyBEZ) encontramos el borrador de una carta, dirigida a Paul Gervais, previniéndole que el artículo de Lista no era más que una copia de los trabajos del mismo Zeballos y Moreno. Evidentemente, Lista no sólo irritó a Ameghino, sino también, a un referente cercano, quien no duda en delatarlo al director del Journal y acusarlo de plagio:
"La publication dont Je vous parle, c'est traduite d'un article de La Tribuna journal de Buenos Aires et elle est signé par Ramon Lista. Ce jeune homme, élève de l'Université, n'a fait qu'un extrait de mes études et ces de M. Moreno".

En efecto, en su nota Lista se contenta de enumerar los hallazgos de Seguin, Ameghino, Bretón y Claraz sin aportar ningún elemento propio. A su parecer, la autenticidad de todos los descubrimientos es "muy sospechosa" si se tiene en cuenta la "condición de los descubridores". Con ello descalifica, sin nombrarlos directamente y con pocos argumentos, la idoneidad de Ameghino junto a Seguin y los hermanos Bretón, estos dos últimos comerciantes de fósiles. Sin duda, Lista conocía informalmente la posición de los integrantes de las comisiones y del Secretario de la SCA y actuaba influenciado por Burmeister, a quién llama su "maestro y paternal amigo" (Lista, 1998:43). En julio de 1879 Paul Topinard le escribe a Ameghino pidiéndole informaciones sobre un tal Ramón Lista "de Buenos Aires" que le solicita la inscripción a la Sociedad de Antropología. Ameghino, a pesar de su amarga experiencia al leer las críticas de Lista publicadas en la prensa, hace gala de honor y lo recomienda firmemente.

Ambos hechos muestran que Lista, en parte protegido por la SCA, pone todos sus esfuerzos en pertenecer al reducido círculo de exploradores y cultores de la antropología y arqueología. Lo logrará sin brillo más tarde, pero vemos que en su juventud, aparecer en el Journal, bien valía un plagio.

El artículo de Lista deja claro que este joven aspirante también confundía el sitio de Frías y el de Rocha. Creía, como Zeballos, que se trataba vagamente del mismo lugar y por lo tanto probaba lo "infundado" de las afirmaciones de Ameghino en el Journal de Zoologie y por extensión, de todas sus obras. Supone así, también erróneamente, que una comisión de la SCA había ya visitado el arroyo Frías y dado un informe negativo. Concluye entonces que la coexistencia hombre-fauna extinta es "un asunto no resuelto y problemático" y atribuye, en línea con Burmeister y Moreno, todos los restos que se encuentran en la provincia de Buenos Aires a los Querandies, tribu que habitaba la región al momento de la conquista española.

Una última oportunidad de poner en justa perspectiva a estos sitios, se malogra en diciembre de 1877, cuando Moreno le solicita 
a Ameghino ver el material, ya casi todo encajonado, presto a ser embarcado a la Exposición Universal de París. Ameghino accedió a recibirlo en Mercedes el 9 de dicho mes, y le sugirió por su intermedio hacer extensiva la visita a Zeballos e invitó, una última vez, a ambos a inspeccionar el Arroyo Frías (Carta n 35, Torcelli, 1935:37), visita que lamentablemente no llegó a realizarse. Sin embargo, Ameghino y Moreno se encuentran por primera vez en enero de 1878, no sabemos en qué circunstancia (Carta 131 en Torcelli, 1935). En busca de legitimidad, reconocimiento y validación externa (Stagnaro, 1994) Ameghino decidió presentar su colección de "armas e instrumentos" en La Exposición Universal de Paris de 1878. A decir de Zeballos (1910:40), lleva "su pleito" a Europa donde obtiene una "completa consagración".

\section{Los medios locales en apoyo de Ameghino}

Para este período inicial de la vida científica de Ameghino, cuando el acceso a publicaciones formales como los Anales de la SCA le estaban vedados, es interesante analizar canales de divulgación alternativos como la prensa. La colección que hace Ameghino mismo de artículos de diarios locales y porteños recortados en folios nos ahorra la búsqueda individual de los mismo en colecciones hoy raras e incompletas de diarios provinciales de la década de 1870 . Torcelli hace referencia explícitamente a este documento en el volumen I de las OCyCC, citando que extrajo datos del cuaderno "que conservan sus hermanos" y "entre los recortes coleccionados". Estos folios se conservan aún y fueron facilitados por Carlos y Juan Ameghino a Torcelli hacia 1912 para la edición de las obras completas, quedando posteriormente en su poder (Torcelli, 1913:11 y 153). En diciembre de 2004 localizamos en el archivo-biblioteca Jorge M. Furt de la estancia Los Talas, un recopilación de recortes de diarios bajo el inventarío "Colección de recortes periodísticos sobre el sabio y su obra en la prensa de Bs As-La Plata e interior". Se menciona que fue adquirido por Furt en 1962 por $500 \$$ en el segundo remate de la biblioteca de Torcelli.

De este cuaderno copia dos artículos "El Tajamar y sus futuras consecuencias" y "Origen de la Tosca" de septiembre de 1875 para rescatarlos del olvido y documentar los primeros ensayos con pretensiones científicas de un subpreceptor de 21 años. La colección consta de 306 páginas dividida dos partes, la primera , con 35 artículos, comienza con un recorte del 4 de ju-

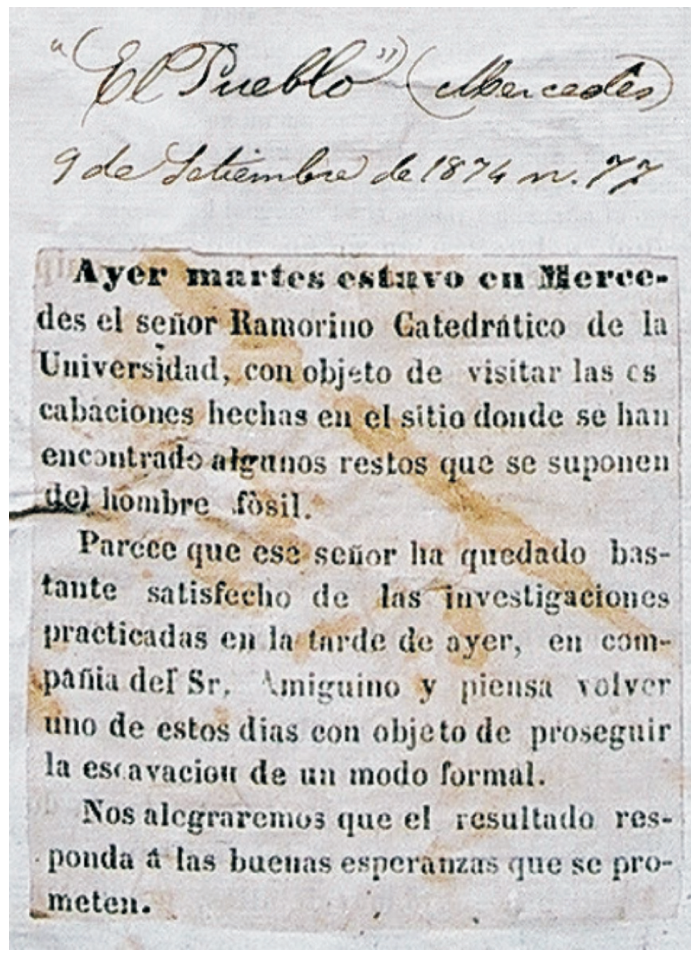

Fig. 19. Artículo del diario "El Pueblo" anunciando la visita del Prof. Ramorino a Frías donde excava junto a Ameghino (Legajo Ameghino, Biblioteca y archivo Furt, Los Talas, Luján).

nio de 1874 de La Nación y termina con otro del 16 de mayo de 1877 de La Razón, luego hay una interrupción y cambio de papel para recomenzar en 1882. Evidentemente y, como también lo señala Podgorny (2014), Ameghino interrumpe la recopilación algunos meses antes de su viaje a Francia y la retoma meses después de su regreso. Recientemente, esta autora hace un estudio de algunos de estos recortes y sugiere que la recopilación fue hecha por Ameghino con la intencionalidad de auto-perpetuarse en una suerte de esbozo de autobiografía latente. Consideramos que no hay ningún indicio de ello, ya que se encuentran intercalados artículos no solo relacionados directamente con Ameghino sino también otros de interés científico general constituyendo un simple archivo documental de su aparición directa o indirecta en la prensa. Zeballos recurre a la misma práctica, su revue de presse denota también una combinación de artículos directamente relacionados a su persona y actividades, y otros de interés general (AyBEZ)). La publicación en diarios tenía en la época un significado cuasi notarial y de referencia certificada. Ameghino recurrirá a esta recopilación como simple fuente bibliográ- 
fica cuando hará una pormenorizada crónica de sus logros y frustraciones respecto al contenido y significación de sus "paraderos" del Luján.

La primera parte de esta revue de presse nos ilustra sobre el reflejo que tenían en la prensa las actividades en el arroyo Frías y los descubrimientos paleontológicos de Ameghino. Los diarios locales "El Pueblo", "La Unión" y "La Libertad" hacen referencia a ellos, así , por ejemplo, queda asentada la visita de Ramorino a las barrancas del arroyo Frías (Fig. 19). Posteriormente estos medios tomarán parte en lo que llamamos la "guerra mediática" con los círculos científicos porteños, en particular en la puja con Lista, hacia quien no escatiman desafíos e ironías públicas (Ameghino $1876,1886)$, como ya lo habían hecho con personalidades políticas como Sarmiento y descubrimientos paleontológicos locales (Podgorny, 2009; Toledo, 2009:88).

Este proceso de vulgarización de las polémicas "diluvianas" y "guerras paleolíticas" es en parte semejante al que había tenido lugar en los medios ingleses como Times y locales franceses de Abbeville, Dieppe y Rouen durante el segundo semestre de 1859 poniendo el debate sobre la existencia del hombre fósil al alcance de todas las clases sociales (Groenen, 1994). En el caso que nos ocupa, el acceso a la prensa local, en particular al diario La Aspiración merece un estudio detallado.

La Aspiración había sido fundada por Luis Alberto Mohr en los primeros días de septiembre de 1875, era de tirada diaria. Luis Mohr (fig. 21), porteño, nace en 1844 , de padre prusiano y madre inglesa, en una familia de negociantes de frutos del país que quiebran a causa del bloqueo anglofrancés. Se inicia en diversos proyectos de negocios en Pergamino, Salto y llega a ser nombrado Juez de Paz de Junín. Debe abandonar esta última abrumado por la presión y manejos de caudillos políticos locales, instalando una procuraduría judicial en Buenos Aires. Sancionada la ley de descentralización de juzgados, se ve obligado al trasladarse a Mercedes de donde dependían de ahora en más los expedientes de sus principales clientes. Para complementar sus entradas ya que su ocupación como procurador estaba aletargada mientras el juzgado terminara su traslado, funda una imprenta para proveer diversos papeles judiciales, publicar edictos etc. y así nace el periódico La Aspiración con el deseo de ser "un diario de todos para todos" (Mohr, 1914:63). Entre 1877 y 1880 lo administra desde Chivilcoy, volviendo a Mercedes luego de la revolución del ' 80 y debe cerrar el diario hacia 1881 por problemas econó-

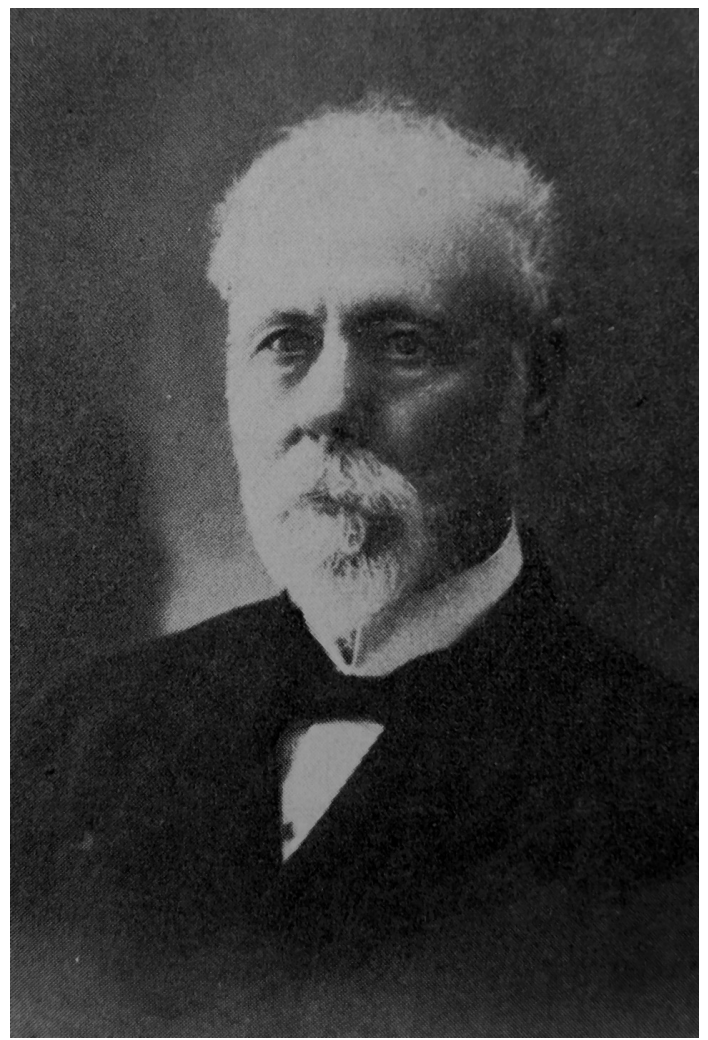

Fig. 20. Luis Alberto Mohr (en Mohr 1904).

micos y la partida de sus socios. La imprenta en venta servirá luego para el diario "La Opinión" en Buenos Aires, medio en que consigue un empleo y donde Mohr una vez más le facilita a Ameghino la publicación de un resumen de su conferencia de la Exposición Continental (OCyCC carta 238). Más tarde es redactor del "Comercial de Buenos Aires”. Sus dos hijos mayores Luis y Alejandro, antiguos alumnos de Ameghino en "segunda sección” en 1876 (La Reforma $n^{\circ}$ 59), trabajaron para "La Republica" y "El Nacional". Mohr, de una personalidad idealista y generosa, tempranamente progresista, entrepreneur de poco éxito y autor de ensayos, puso el diario y la imprenta a disposición de Ameghino con quien compartía un escritorio frente a la plaza de Mercedes:

"Allí él hacia su colección y estudio de fósiles. Alli anotaba sus escrupulosas observaciones, meditando y escribiendo durante largas horas. $Y$ alli también cuando podía y como podía, leía las obras científicas que trabajosamente obtenía. Allí, a mi vez, escribía yo para mi diario y recibía y corregía las pruebas de 
imprenta [...] Ameghino luchaba y sufría, y yo también sufría y luchaba" (Mohr, 1914:191)

Con el beneplácito de Mohr, Ameghino dispone gratuitamente del diario y sin duda con facilidades de su imprenta, entre septiembre de 1875 y febrero de 1876. Allí imprime su trabajo sobre la Banda Oriental en 1877. En los folios de recortes solo encontramos un artículo firmado por Ameghino de La Aspiración, el referente al origen de la tosca. Los tres restantes, del 20 de noviembre, 16 de enero y 30 de julio con temas ameghinianos, no tienen firma y muy probablemente fue Mohr mismo quien los redactó para impulsar a su compañero de sufrimientos y luchas.

En el primero de ellos leemos que "Desde su fundación, Ameghino dispone gratuitamente de las columnas de La Aspiración", y se elogia abiertamente la figura del "educacionista de insignificante sueldo" con alabanzas a su personalidad y publicitando el premio de estímulo recibido en el concurso de la SCA en 1875. En el artículo del 16 de enero anuncia el descubrimiento Cañada de Rocha que será replicado en Buenos Aires por La Nación, haciendo oficio de comunicado a los miembros de la SCA y, en la nota de fines de julio de 1876 informa que los borradores de la futura "Antigüedad del hombre en el Plata" estaban muy avanzados. Como hicieran los diarios de Abbeville, Mohr promete que:

\begin{abstract}
"La cuestión que pretende haber resuelto el Sr. Ameghino es de tanta importancia que así que obtengamos copia de esas comunicaciones, las publicaremos para poner al corriente a nuestros subscritores de las discusiones que se vayan originando sobre un descubrimiento verificado en esta localidad y que quizás más tarde haga celebre en el mundo científico el nombre de Mercedes"
\end{abstract}

No tenemos registro que Ameghino haya publicado los futuros intercambios con la SCA en este diario pues Mohr hacia fines de 1876 pierde la imprenta y debe mudarse a Chivilcoy. Ameghino y Mohr solo se volverán a cruzar por intercambio epistolar en 1887 y en 1905 cuando Mohr le envía ejemplares de sus ensayos (Mohr, 1914:191 y OCyCC carta $n^{\circ}$ 471-472). La cuestión "eolítica" seguirá dirimiéndose en parte en la prensa. Como viéramos más arriba, desde la excursión de Zeballos y Reid en 1876 Ameghino solicitará sin éxito la inspección de sus sitios "eolíticos" de Luján y Mercedes y los materiales allí extraídos. Se lo propondrá airadamente a Lista en 1877 en el diario La Libertad, esta vez ya retándolo a un "desafío" o "debate científico". Cinco años después por medio de La Nación (número del 5 de Julio de 1882 y carta 239 en Torcelli, 1935) reaccionó implacablemente a lo dicho por el ingeniero Eduardo Aguirre en una conferencia sobre la formación Pampeana, invitándolo, no sin ironías y animosidad, a una excursión por los parajes citados y anuncia una "conferencia pública especial" para refutar los dichos del profesor de la Facultad de Ciencias Exactas y Naturales:

“[...] no hay nada perdido. Hágalo, acompáñeme en una excursión a orillas del Luján en Luján y en Mercedes, y le mostrare capas vírgenes, a profundidades considerables [...] podrá exhumar con sus propias manos vestigios materiales de la existencia del hombre con esa época. Hágalo, y aprenderá muchas cosas que aun ignora sobre el terreno pampeano"

Aguirre contesta a los pocos días al director de La Nación con cierto desdén, desvalorizando la crítica de Ameghino al considerarlo un autor intransigente e irreflexivo. Esta será la última vez que Ameghino propone un duelo científico sobre sus descubrimientos del Luján. Dicho desafío, fundamentalmente en sus aspectos arqueológicos, sigue aún vigente.

\section{Los restos humanos, Frías I (1870) y Frías II (1873-1874)}

Como se señaló anteriormente, Ameghino realizó un primer hallazgo en 1870 (Ameghino 1889, Torcelli 1935) de un esqueleto completo y articulado Frías I (sensu Lehmann-Nitsche, 1907). Estos primeros restos recuperados sin mayor cuidado los vendió al comerciante de fósiles y antiguo preparador del Museo Público, Antonio Pozzi, quien los habría depositado o vendido al museo de Milán. Más tarde, en noviembre de 1880, al comprender el valor de los restos, Ameghino le escribe desde Paris a Emilio Cornaglia (director del Museo Cívico de Milán) para localizar los restos supuestamente allí depositados por Pozzi. Cornaglia le contesta diciendo que solo tenían una colección comprada a Pozzi en 1872, sin restos humanos (OCyCC, Vol. 20, cartas 125 y 126). Posteriormente, Roth en 1890 y Morselli los trataron de localizar, sin éxito, en 


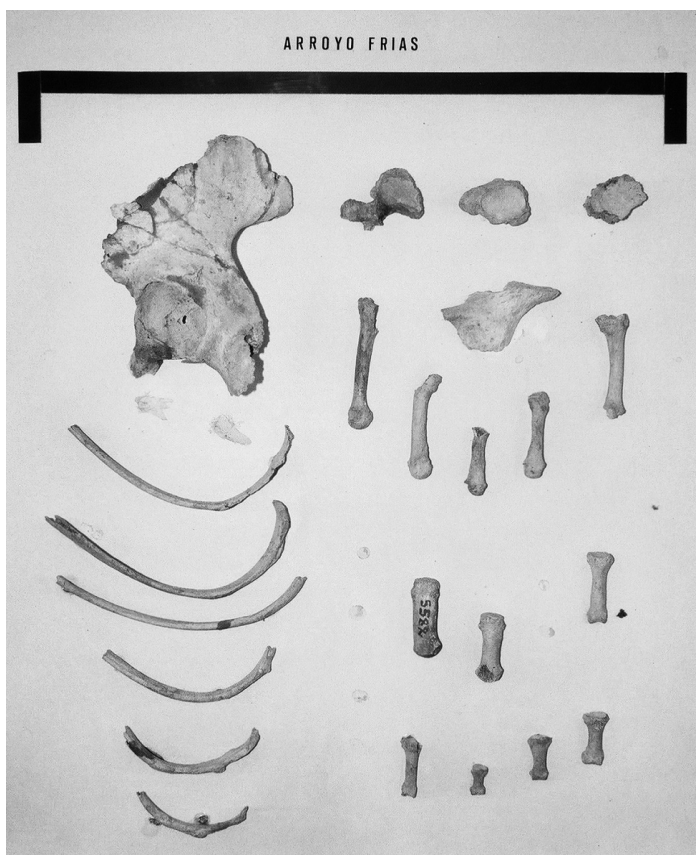

Fig. 21. Restos óseos de Frías II como eran exhibidos al público en el Museo de La Plata hasta 2006.

esta misma institución italiana. Tal vez, Pozzi nunca los depositó allí a lo que hay que agregar que lamentablemente, las antiguas colecciones de dicho museo fueron parcialmente destruidas en la segunda guerra mundial (Casinos, 2012:408). Como bien señala Orquera (1970) es llamativo el hecho que Ameghino no hable de este primer hallazgo en su síntesis de 1881, donde sin embargo, le dedica todo el capítulo XVII a los hallazgos que hiciera exactamente en el mismo lugar en 1873. Recién más tarde, en su obra de 1889, cita su primer hallazgo. Al momento de su muerte estaba realizando una revisión de su actividad geo-arqueológica lujanense y allí retoma en detalle los sucesos de 1870, obra que lamentablemente queda incompleta y trunca.(Les problèmes geo, archeo et paléoanthropologiques de l'Argentine. A Propos du nouveau livre du Dr. Lehmann-Nitsche. OCyCC, tomo XIX:708-928. Reproducción póstuma de los borradores truncos copilados por Torcelli).

Sin embargo, en su Antigüedad del hombre en el Plata Ameghino describe en detalle los descubrimientos realizados en 1873-1874 o de Frías II (Fig. 21), siguiendo la nomenclatura de Lehmann-Nitsche; exactamente en el mismo punto del primer hallazgo, o Frías I, de 1870. Allí volverá a cavar entre septiembre de 1873 y de 1874. En dos cartas al agrimensor y coleccio-

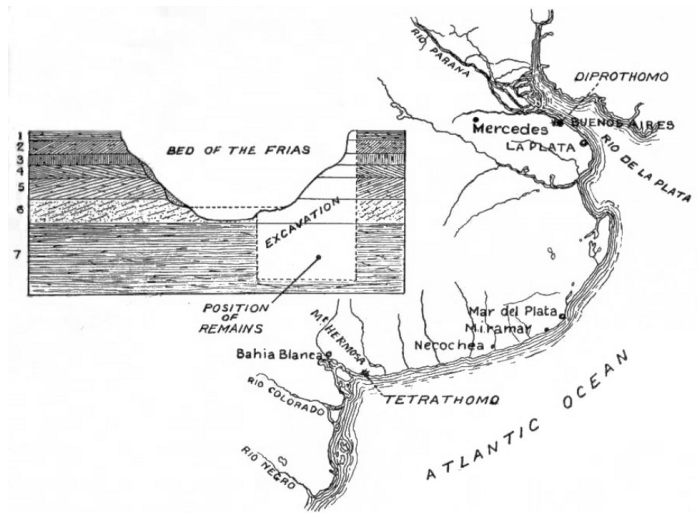

Fig. 22. Ilustración de los sitios de Ameghino y corte de Frías (Keith, 1916)

nista Manuel Eguía (archivo Museo Ambrosetti 82-6 1873/9/19, carta $\mathrm{n}^{\circ} 3$ en Torcelli, 1935; y 82-6 1873/10/10, inédita), hacia septiembre de 1873 menciona que ya había extraído la mayoría de los restos. En enero de 1874 presentó sus descubrimientos personalmente a Burmeister (Ameghino, 1881:378) quien los minimiza con desdén, sin darle importancia alguna. En septiembre del mismo año excavó junto a Ramorino. Ameghino en 1881 y 1889 deja en claro que ambos descubrimientos proceden de distintos niveles, si bien en sus escritos póstumos los considera como pertenecientes a un mismo individuo:

"Los vestigios de la antigua existencia del hombre y los huesos humanos se encontraron en la penúltima capa al nivel del agua del arroyo, y más abajo en la última capa hasta un metro por debajo del fondo del cauce del mismo" (Ameghino, 1889:66).

"Los huesos humanos que he recogido en este punto, en el fondo de la excavación, en la capa $n^{\circ} 9$ (Figura 590), son bastantes numerosos" (Ameghino, 1881:491).

Ameghino lleva consigo estos restos a París y son examinados por varias personalidades y principalmente por el Profesor Broca quien realiza una nota que Ameghino adjuntará a su artículo "Armes et instruments de l'homme prehistorique des pampas" (Ameghino, 1880a). Broca dedujo que los restos pertenecen a una mujer senil y de pequeña estatura, menor a $150 \mathrm{~cm}$. Los restos se componen principalmente de costillas, falanges, algunas vértebras, huesos del pie y el coxal iz- 


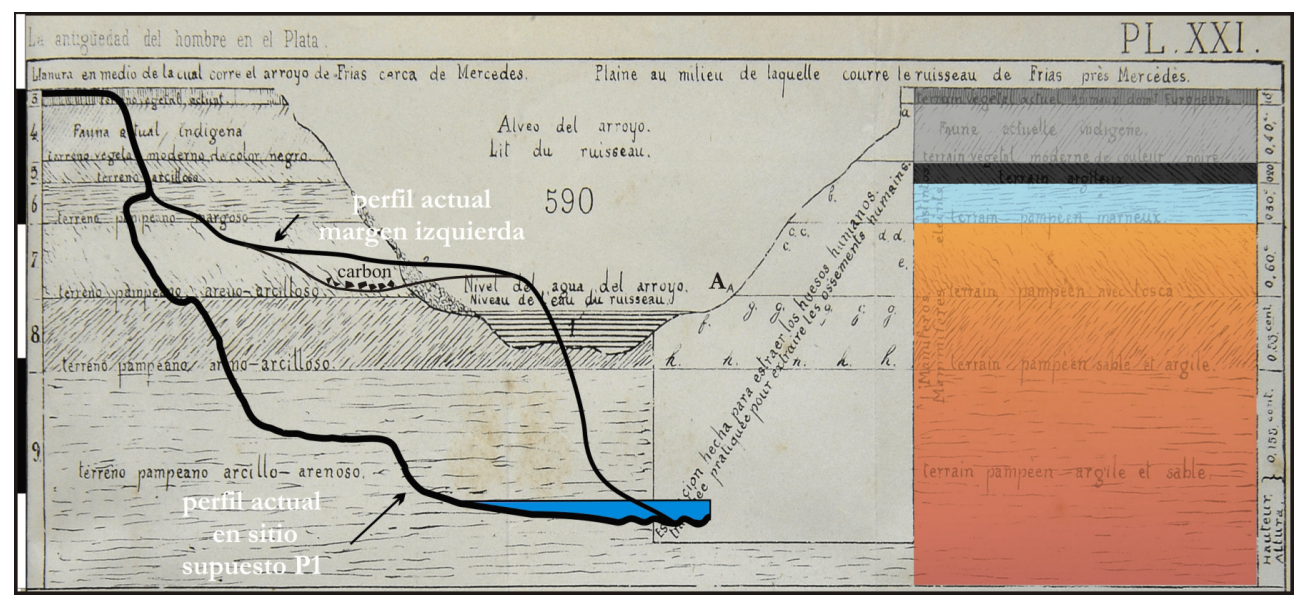

Fig. 23. Cortes publicados por Ameghino (1878, 1881) del sitio de excavación de Frías, nótese el perfil de la barranca actual (Fig 9) superpuesto al gravado y diferencias de profundidades.

quierdo. Los restos de la mano y del pie serán estudiados en 1906 a pedido de Lehmann-Nitsche (1907:243) por el anatomista Leboucq de Gand, quien recibe restos pertenecientes a la mano derecha, izquierda y al pie derecho. Deduce que los restos provienen de dos individuos, uno masculino y otro femenino senil. El descubrimiento no le deja lugar a dudas a Ameghino sobre la alta antigüedad del hombre en la pampa, presente al menos en su "Pampeano Superior", que cree terciario, y evidentemente asociado a la megafauna:

\section{"este descubrimiento de huesos humanos, silex tallados, huesos trabajados y quemados, carbón vegetal, tierra quemada, huesos de animales extintos, etc., etc. todo ello mezclado y recubierto por tres metros de terreno no removido, es decisivo y resuelve el problema de la coexistencia del hombre con los animales extinguidos, de un modo afirmativo y que no deja lugar a dudas" (Ameghino, 1881:495)}

Aun así presentó un extenso análisis (Ameghino, 1881:483-511), que él mismo llamó una "larga y escrupulosa disertación", de cada una de las objeciones que le podrían hacer los "impugnadores sistemáticos", sin duda refiriéndose entre otros a Burmeister, Moreno y Lista. Pasa revista así, y con detalladas argumentaciones, pruebas y contrapruebas a las posibles críticas a su tesis: posición del sitio en el pampeano superior; posición in situ, extracción en terreno no removido, e imposibilidad de inhumación reciente y descenso estratigráfico de objetos. Este análisis, más allá de los aciertos y errores muestra claramente la rigurosidad y actualidad de criterios de Ameghino al observar los factores de formación de sitio.

\section{Frías revisitado en el siglo $\mathrm{XX}$}

Ameghino hacia 1911 redactaba un libro con la revisión de todos los hallazgos del noroeste de la provincia de Buenos Aires, casi todos acaecidos en la segunda mitad del siglo XIX. Ameghino vuelve a los lugares y objetos de sus inicios en reacción a la revisión de Lehmann-Nitsche publicada en 1907 y posiblemente en parte porque presentía que el corpus de conocimientos ge-arqueológicos del valle de Luján era más sólido estratigráfica y arqueológicamente que los hallazgos de la costa atlántica bonerense. Por otro lado estos sitios habian caído en el olvido quedando así al margen de los tensos debates sobre el origen patagónicopampeano del género Homo. En estas notas póstumas sobre Frías (en Torcelli, 1935) Ameghino retoma las circunstancias de hallazgo de 1870 y los supone como pertenecientes al mismo individuo exhumado en 1873/74. Hrdlicka (1912) analizó los trabajos de Ameghino de 1881 y de Lehmann-Nitsche (1907), y prefirió explicar las condiciones del hallazgo como un enterramiento reciente efectuado en el cauce mismo durante un período de sequía. Por otro lado, atribuyó poco valor a las descripciones de Ameghino por considerarlo todavía inepto como geólogo, y relativiza el aspecto fósil de los huesos. Es llamativo que acepta los huesos partidos y rayados de megafauna como prueba de la acción humana lo que le lleva a especular y forzar, curiosamente, 


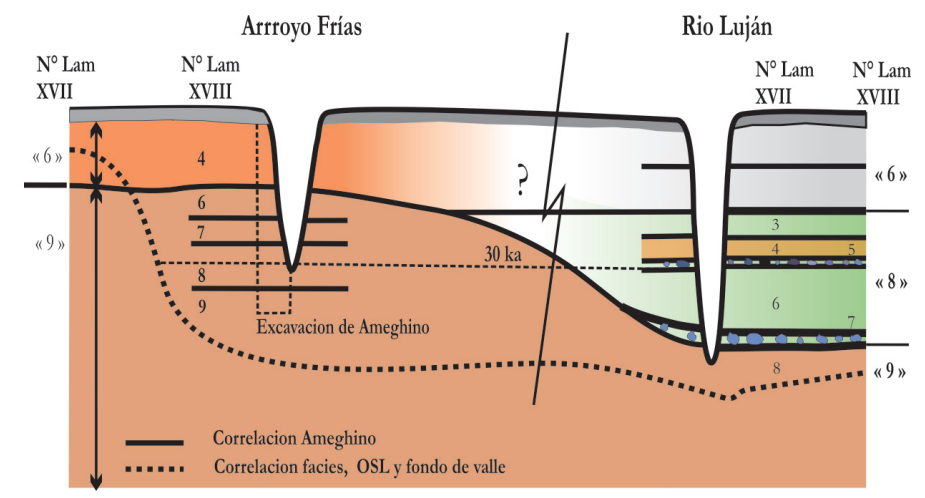

Fig. 24. Esquema estratigráfico comparativo de los cortes de Frías y Luján y su correlación según Ameghino (1881) y la correlación aquí propuesta.

una posible fecha de extinción muy reciente. Las primeras revisiones sistemáticas de los hallazgos de Ameghino sobre el "hombre fósil" o "early man" con control de campo por geólogos serán las de Burckhardt en noviembre 1899 y B. Willis en mayo de 1910, publicadas en 1907 y 1912 respectivamente (en Lehmann-Nitsche et al., 1907 y Hrdlicka et al., 1912). Sin embargo, ninguno de ellos visitará el valle del Río Luján y se concentran en los sitios del rio Salado y de la costa atlántica. Hrdlicka realiza solo un análisis bibliográfico de Frías, sin examinar el material de los "paraderos" que si había estudiado Lehmann-Nitsche, pero ninguno de los dos equipos intentará relacionar la estratigrafía lujanense y los objetos hallados con un control de campo. En las notas preparatorias a una crítica del libro de Leman-Nitsche, Ameghino señala claramente que Burckhardt no había visitado las "localidades clásicas de Luján y Mercedes". Ameghino muere en 1911 de modo que deja trunca la crítica Lehmann-Nitsche y no podrá reaccionar al detallado y demoledor reporte de Hrdlicka y colaboradores de 1912.

El hallazgo de Frías no solo retoma renombre internacional hacia principios del siglo XX con las revisiones de Lehmann-Nitsche y Hrdlicka sino que figura en obras de síntesis como The antiquity of men (Keith, 1916) donde los descubrimientos de Ameghino (Fig. 22), (con énfasis en el de Frías), tienen el raro privilegio de preceder un extenso y tan detallado como falso análisis del Eanthropus dawsoni u hombre de Piltdown, declarado un ensamble fraudulento recién 40 años después (De Grotes, 2016). La única revisión no solo bibliográfica sino con inspección in situ de un sitio ameghiniano del Luján será recién hecha por Orquera en 1970 (Orquera, 1970). En la misma época, un reconocimiento expeditivo al sur del puente viejo es realizado por Alan Bryan y Ruth Gruhn sin encontrar ninguna evidencia arqueológica (Ruth Gruhn, com. pers.)

\section{Geoarqueología}

Posición estratigráfica de Frías I y II. El 20 de septiembre de 1873 Ameghino encontró restos de gliptodonte que supuso pertenecientes el género Hoploporus a nivel del agua en el punto indicado como "a" en el corte de la Fig. 23. Al extraerlos encontró otros fósiles y una materia oscura que interpretó como carbón en el límite entre las capas 8 y 9 (Figs. 2 y 3 ). Decide continuar la excavación ya que los restos de carbón eran más abundantes hacia abajo; y, mezclados con ellos, encuentra huesos humanos en la parte superior de la capa 9. Frente a tal descubrimiento organiza una excavación de grandes dimensiones incluida la construcción de un pequeño dique para poder cavar bajo el nivel del arroyo. Trabaja ayudado por dos peones y llega a así a cavar 1,50 metros por debajo del cauce. Ameghino denomina a este sitio como "Paradero Numero 1", ya que lo considera el más antiguo basándose en sus interpretaciones estratigráficas.

El perfil de detalle del sitio de Frías que proporciona este autor, muestra una sucesión de capas "rojizas" por debajo de la tierra vegetal (Figs. 23 y 24). Estas capas, que enumera de 6 a 9, poseen fauna extinta y reconoce que su división es algo arbitraria ya que los límites entre ellas son "difusos". Las diferencia según un mayor o menor contenido de arena respecto a la fracción arcilla, y el contenido de concreciones calcáreas. Es decir, que los fósiles humanos y el material lítico asociado se encontraban, para Ameghino, en pleno sustrato de los valles pampeanos, en sedimentos depositados en los tiempos "pampeanos", anteriores al "pampeano lacustre". Por lo tanto, el sitio debería ser anterior a la erosión de los 


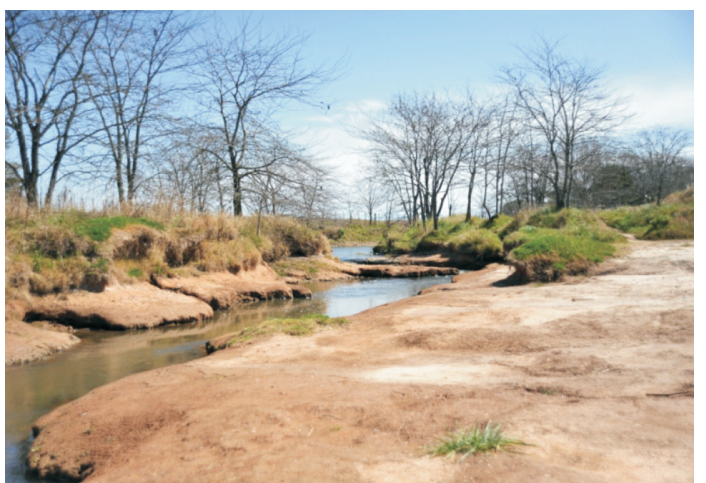

Fig. 25. El arroyo Frías agua arriba del puente de cemento actual en el nuevo camino a Giles, con profundidades de incisión menores, más cercanas a las que describiera Ameghino (1881).

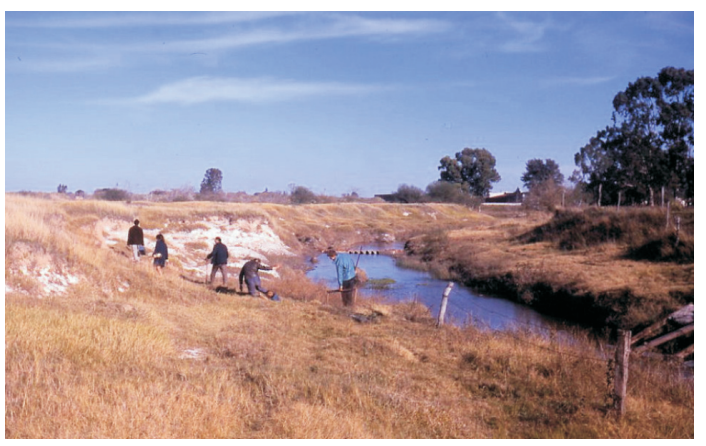

Fig. 26. Barranca del arroyo Frías agua abajo del puente metálico en 1970 (Foto Gruhn). En esta campaña participaron Alan Bryan y Ruth Gruhn, Jorge y Beatriz Petrochelli, H Lagiglia, H. Burgos y L Villanova.

valles, rellenados luego por su "pampeano lacustre" y "postpampeano lacustre" y, entonces sin duda alguna, Plioceno (Fig. 23).

No observa conglomerados basales, ni sus capas "blanquizcas" del pampeano lacustre de su "Paradero $\mathrm{n}^{\circ}$ 2". En 1889 refiere claramente que en el punto de hallazgo no existe el "platense" ni "Lujanense" sino el "Pampeano Superior" bajo la cubierta de humus. Deduce entonces, y veremos que erróneamente, que todas estas capas rojizas pertenecen al Pampeano Superior equivalente hoy a la Formación Buenos Aires. (Fig. 24).

$\mathrm{El}$ análisis de las distintas referencias al sitio de Frías (Ameghino, 1875, 1879 a y b, 1880, 1881 y 1889) deja ver que en 1870, Ameghino tiene solamente 16 años, exhuma un esqueleto casi entero, articulado y del que describe su posición. Estos restos parecen estar algo por debajo del nivel normal del agua del arroyo, en la "penúltima capa" (capa 8) ya que los descubre gracias a una gran sequía.

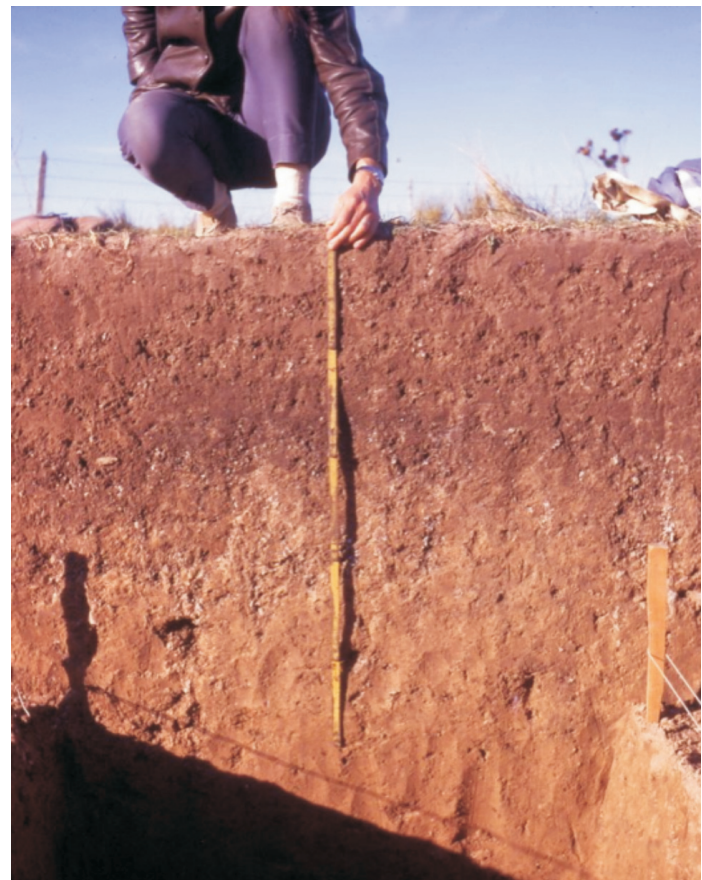

Fig. 27. Excavación Gruhn agua abajo del puente metálico actual en la margen izquierda (foto Gruhn).

Al contrario, para el hallazgo de 1873 refiere que los restos humanos están dispersos al menos en unos $20 \mathrm{~m}^{2}$ y un metro por debajo del fondo del arroyo, en la "última capa", es decir la capa 9 de su corte (Fig. 22) y que trabaja con el apoyo de varios peones hasta no encontrar más objetos, lo que lo lleva a cavar más de un metro por debajo del pelo de agua. Esto sugiere que podría ser un sitio multicomponente, uno de ellos, el más profundo, no sería un enterratorio y los restos pertenecerían a individuos diferentes y de antigüedad también diferente. En Paris, Cope le solicita un resumen de su hallazgo para la revista American Naturalist lo que constituye la primera publicación del corte estratigráfico. Orquera (1970, 1971) analizó en detalle los diversos relatos de Ameghino, que al confrontarlos muestran, según este autor, ambigüedades y contradicciones. Concluyó, en contra de los dichos de Ameghino, en que los restos pertenecerían a un mismo nivel, tope de la capa 9, y que Ameghino los habría mezclado involuntariamente en su segunda intervención. Sin embargo esta posibilidad, que fue analizada y negada por Ameghino mismo (1881:500), nos parece poco probable dado que la consistencia del terreno, la extensión y profundidad muy diferentes de ambas excavaciones y, sobre todo por el hecho que Ameghino declaró 


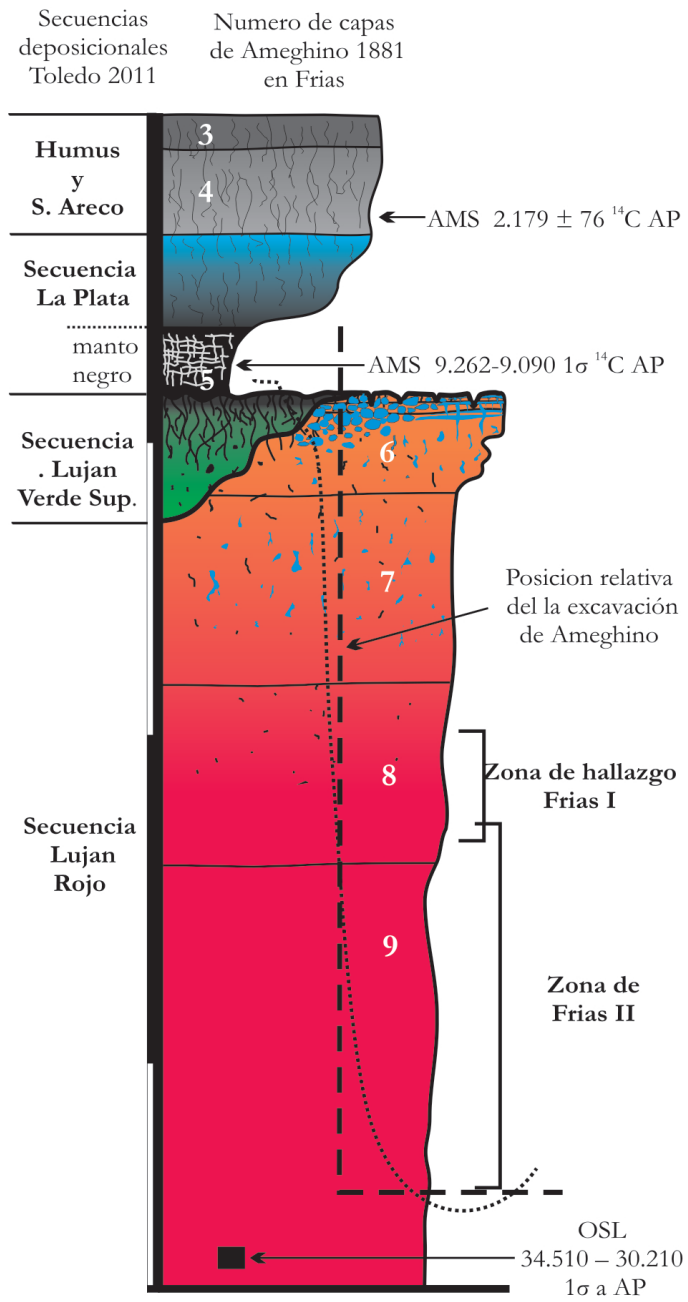

Fig. 28. Columna estratigráfica generalizada para el valle del arroyo Frías. Se incluyen las capas de la Secuencia La Plata y Luján Verde superior, que no se encuentran en la margen izquierda del arroyo Frías entre los puentes actuales.

que en 1873 cavó la capa 9 con extremo cuidado, con su "propias manos", avanzando lentamente con un cuchillo con el que cortaba "rebanadas de sedimento".

Se debe señalar que descubrimos en la edición de 1918 (La Cultura Argentina) de La Antigüedad del Hombre en el Plata (Ameghino [1881] 1918), una errata de imprenta en la página 270, que cambia el número de capa 9 por 6 , respecto al original (menos consultado), de 1881 (página 485). Esta errata no detectada antes, indujo a Orquera (1971:108), al trabajar solo con la edición de 1918, y tras un largo análisis, a considerar erróneamente la correlación de Ameghino

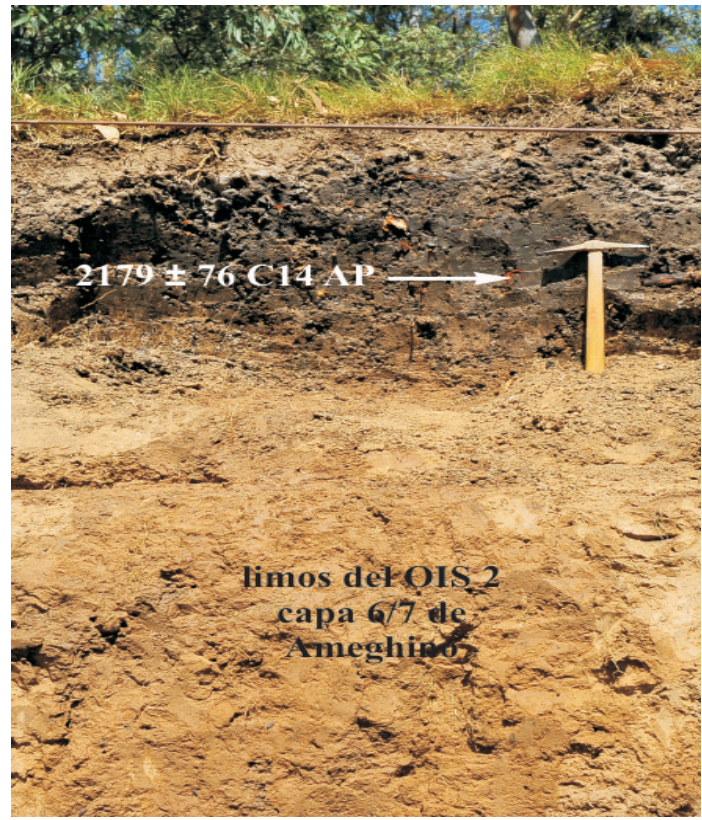

Fig. 29. Sección superior del perfil del arroyo Frías en sitio de la Fig. 9.

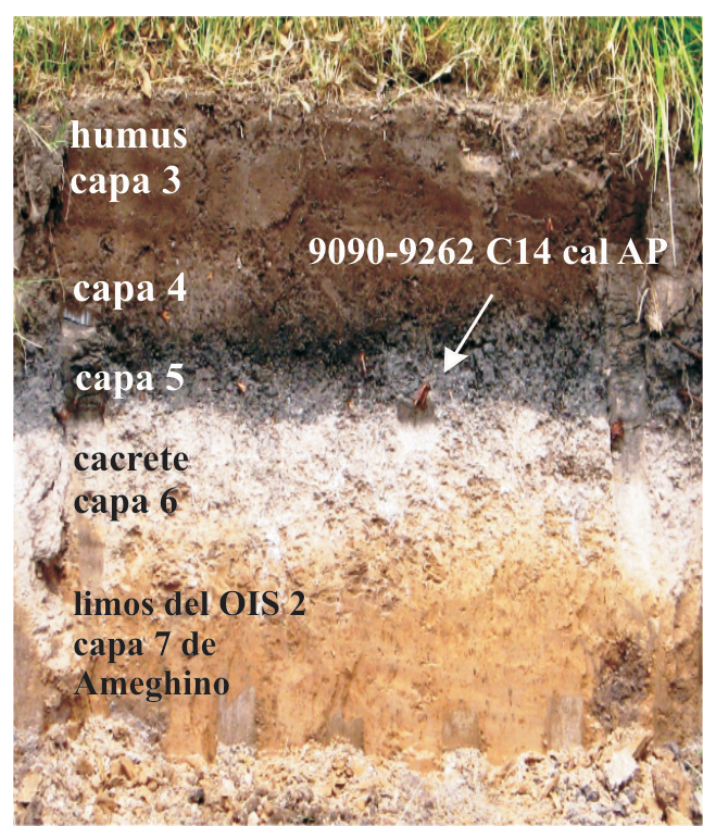

Fig. 30. Mantos negros apoyando directamente sobre complejos pedocálcicos y facies loessoides Lujanenses, perfil de la cuneta del camino a Giles, punto de la datación AMS (Fig. 3).

como absurda y una prueba más de la lógica deficiente de Ameghino. También mal interpreta el texto en inglés de Hrdlicka a quien acusa in- 
justamente de una falla de lógica. Asimismo, los objetos líticos son minimizados hasta considerar normal la presencia de fragmentos líticos con filos naturales en medio de la llanura bonaerense (Orquera, 1971:120).

Luego de un extenso análisis en que juzga los errores y/o imprecisiones de Ameghino, Hrdlicka, Lehmann-Nitsche y otros, este autor introduce otros, como el inducido por la no utilización de la edición original, junto a argumentaciones ambiguas de índole geomorfológico y paleomorfológico al no considerar la evolución del paisaje y la cronología de la incisión actual. Descarta todo valor de los restos de Frías, que califica de "excesivamente insignificantes" (Orquera, 1970:346) concluyendo:

\section{"su estudio pertenece a la historia de la ciencia y no a la ciencia misma" (Orquera, 1970:130)}

Estratigrafía. La inspección in situ muestra que todas las capas tienen un grado de consolidación importante y aún hoy se distinguen por diferencia textural los sedimentos extraídos y acumulados en el borde norte de la antigua excavación hace 55 años (Fig. 10). Por lo tanto es casi imposible que Ameghino confundiera terreno removido por él mismo, menos de tres años antes, con depósitos vírgenes como propone Orquera (1970, 1971).

Ameghino encontró en 1873 los huesos humanos "al fondo de la capa 9" lo que implica que, teniendo en cuenta sus medidas, el nivel con dichos restos se encontraba a una profundidad cercana a 3,40 metros de la superficie del suelo de la llanura circundante.

El modelo estratigráfico desarrollado para el valle del río Luján (Toledo 2009, 2011) más observaciones puntuales del valle del arroyo Frías permitieron encontrar la correspondencia entre la mayoría de las capas de Ameghino $(1881)$ y las que se observan actualmente (Fig. 28, 29, 30). Siguiendo el orden de Ameghino, luego del humus (capas 3 y 4), se encuentra su capa 5 "muy arcillosa" que corresponde a suelos hidromórficos ricos en materia orgánica, luego la capa 6 o "terreno pampeano margoso" que corresponde a un complejo pedocálcico, desarrollado a expensas del techo de la secuencia Lujanense Rojo (LR), posiblemente entre 13 y 16 ka., durante el depósito de la secuencia Lujanense Verde Superior (LVs) con mayor humedad estacional. Las capas 7, 8, 9 las interpretamos como todas pertenecientes a la secuencia Luján Rojo (LR), no se observa una

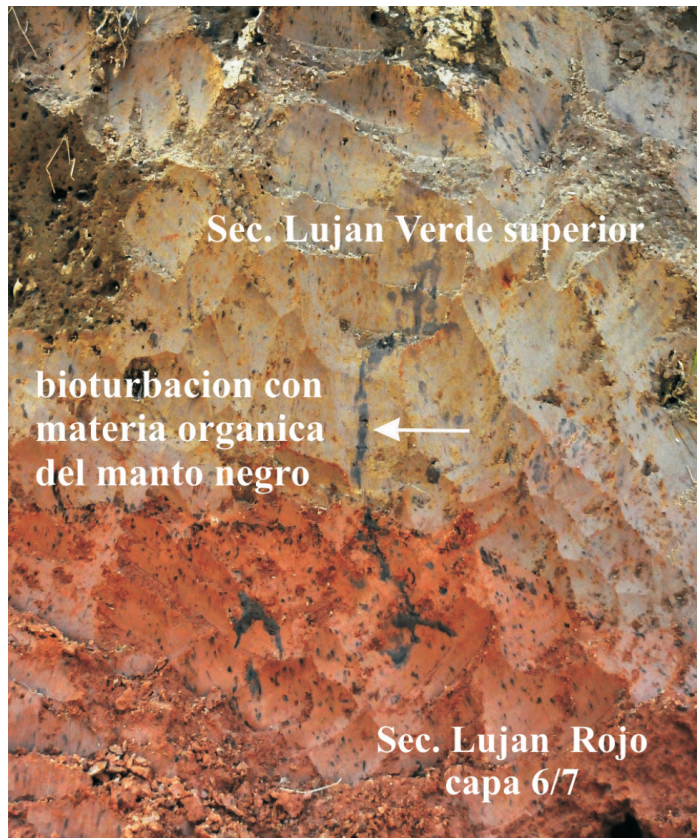

Fig. 31. Depósitos de la Secuencia Luján Verde superior (o Miembro Guerrero "verde"), agua arriba del puente de cemento actual, en discordancia sobre facies de llanura de inundación de la Secuencia Luján Rojo.

diferenciación evidente entre ellas y representan facies loessoides con diferente participación de procesos eólicos, fluviales y pedológicos del último pleniglaciar. Estos limos se habrían depositado entre 16 y 30 ka AP (Toledo, 2011). Una datación de OSL para los niveles loessoides extraída en el borde sur de la excavación, a 3,8 metros de la superficie de la llanura, determinó una edad de 3034 ka AP (Schewenninger, 2009; Tabla 1 y Fig. 26).

Ello indica que los niveles loessoides pertenecen sin duda a una amalgamación de eventos de redepositación fluvial y eólica de las secuencia LR y LVs con edades entre $30 \mathrm{k}$ AP y $13 \mathrm{k}$ AP, y no al "sustrato" o Formación Buenos Aires como supuso Ameghino, confusión frecuente aun en la actualidad (Toledo 2011:145). Por otro lado, a unas decenas de metros aguas arriba del puente de cemento o "nuevo", se conserva la secuencia LVs en facies verdosas típicas, acuñándose hacia el sur, y lateralmente, es decir hacia la posición supuesta del sitio de Frías (Fig. 25, 31).

De todo ello se deduce que, las capas rojizas de Frías no se correlacionan, como propone Ameghino, con las de la sección basal del "Paradero 2", en cambio sus capas 6, 7, 8 y 9 del "Paradero 1" o de Frías, se correlacionan con las capas 3, 4 y 5 de su "Paradero 2 " de Luján (Fig. 23), todas suprayacentes a su "pampeano superior". 
Se debe señalar que estos sedimentos rojizos poseen inclusiones de arcilla rica en materia orgánica, oscuras, bien definidas, aisladas en la masa rojiza y posiblemente correspondan a los restos que Ameghino interpretara como carbón degradado por la humedad en su "capa 9" y que son en realidad intrusiones de arcilla y materia orgánica a través de canales radiculares de los suelos hidromórficos o mantos negros del holoceno basal (Fig. 30 y 31). Orquera (1970) observa estas inclusiones en su capa IV e indica igualmente que podrían corresponder a lo que Ameghino interpretara como carbón. En 1889 Ameghino mencionó claramente que faltan en Frías los pisos Lujanense y Platense:

\section{"En este punto faltan por completo las formaciones de los pisos platenses y Lujanenses, presentándose inmediatamente debajo de la capa de tierra vegetal [...] el pampeano rojo superior" (Ameghino 1889:65).}

Ello se explica pues el cauce actual fue inciso en el lateral este del valle donde la Secuencia Luján Rojo había tenido un desarrollo importante faltando las secuencias LVs y la mayor parte de la secuencia La Plata (Toledo, 2011).

Orquera (1970) realizó una trinchera en la barranca opuesta de la excavación mencionada y describió sedimentos verdosos del Lujanense, posiblemente del LVs que se pueden correlacionar con los que observamos cerca del puente carretero o "nuevo". Es interesante señalar que Alan Bryan y Ruth Gruhn, luego de asistir al Primer Congreso de Arqueología Argentina, realizaron prospecciones en el arroyo Frías en su margen izquierda aguas abajo del puente viejo (Fig. 26 y 27). Ruth Gruhn nos facilitó amablemente la trascripción de su diario de campo que documenta dichas actividades:

\section{"6 June 1970: At 8 am left for Mercedes} with two of Rex Gonzales' students to look for several of Ameghino's sites of last century. Pampa. Spent some time looking along bank of Arroyo Frías but nothing found-deposits for ca. $10 \mathrm{ft}$. above water level appear to be alluvium, probably recent; material within redeposited. 7 June 1970: Spent day excavating cut on side of stream bank of Arroyo Frías. Trench to depth of $2 \mathrm{~m}$ revealed only modern soil profile, with nodules of Ca very hard and large, formed in desiccation cracks.

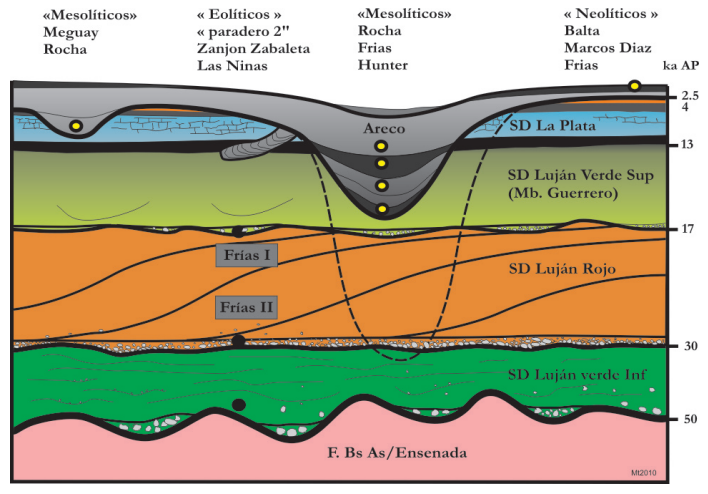

Fig. 32: Modelo deposicional para las secuencias aflorantes en la Pampa Ondulada y la posición estratigráfica relativa de sitios arqueológicos históricos, "paraderos" de Ameghino y sitios excavados recientemente.

\section{June 1970: returned to La Plata in the morning..." (Fig. 8, 28, 29).}

Politis et al. (2011:47) atribuyen, sin un análisis geoarqueológico in situ, las capas portadoras del material cultural al miembro Guerrero "superior" de la Formación Luján (secuencia LVs), por debajo del paleosuelo Puesto Callejón Viejo que no se presentan en el supuesto punto del hallazgo, ni su presencia se puede inferir en las descripciones litológicas de Ameghino y menos aún en las fotografías blanco y negro de Orquera (1970b) y de Politis y Bonomo (2011). Estos autores también dan como opción que los restos podrían provenir del techo de la "Formación Pampeana" es decir la Formación Buenos Aires. El análisis de facies y cronológico permite desechar esta posibilidad ya que como fue descripto no se encuentra tampoco en este punto dicha formación aflorante, sino que solo se encuentran limos loessoides rojizos "Lujanenses".

La observación de las características geomorfológicas del valle permitió también poner en evidencia ciertas incoherencias entre las dimensiones aportadas por Ameghino y el cauce actual en el punto supuesto (Fig. 23). Este autor señala que el nivel de las aguas del arroyo en el "Paradero 1" se encuentra a unos $170 \mathrm{~cm}$ de la superficie de la llanura, y la profundidad del cauce entre $200 \mathrm{y}$ $230 \mathrm{~cm}$. Sin embargo, entre los dos puentes actuales las barrancas poseen hasta el pelo de agua medio unos tres metros, aun teniendo en cuenta los trabajos de rectificación recientes del cauce.

Sólo, al norte del puente carretero, y gracias a resaltos naturales del cauce del arroyo, las barrancas se acercan más a los valores dados por 
Ameghino, donde aflora su "pampeano lacustre" verde que parece no haber identificado, ya que no lo nombra en ninguno de sus escritos (Fig. 25, 31). Cabe considerar la posibilidad de acción de erosión retrogradante en solo un siglo o que la escotadura en la barranca citada no corresponda al sitio de Ameghino. Actualmente se observa un nivel de terraza a media altura de la barranca. Se contempló la posibilidad de que las medidas de Ameghino se iniciaran en este resalto y, no en el nivel general de la llanura, pero esto último no sólo se contradice cuando describe al arroyo Frías como un curso con barrancas cercanas a los "dos metros respecto al nivel de la llanura", sino también con el perfil geológico observable. Otra posibilidad es que Ameghino dibujara el perfil años después en París a pedido de Cope en 1878, de forma aproximada, estimando espesores según sus recuerdos.

Por otro lado, los restos de Frías extraídos en 1873 y depositados en el Museo de Ciencias Naturales de La Plata fueron datados por AMS en edades calibradas ${ }^{14} \mathrm{C} 2 \sigma$ entre 10.550 y 12.750 AP, (Politis et al., 2011, Politis y Bonomo, 2011), período de máximo desarrollo de humedales en estos valles (Toledo, 2009b, 2011). Si esta edad es correcta, debería tratarse, evidentemente, de un enterratorio netamente intrusivo en capas de la secuencia LR, y por otro lado implica considerar que si se realizara un enterratorio hacia $11 \mathrm{ka} A P$, cuando el valle se encontraba colmatado aproximadamente a nivel de la "capa 5" de Ameghino (1879b, 1881) o de mantos negros, hubiera sido necesario practicar una fosa de unos dos metros desde dicha superficie, ya que la incisión del cauce es considerablemente reciente.

Las dataciones del manto negro a $300 \mathrm{~m}$ del sitio en borde de valle oeste con edades mínimas de 9 ka AP (Tabla 1, Fig. 3 y 30), también presentes en el área entre ambos puentes, confirmarían la existencia de un pantano somero entre 11 y $9 \mathrm{ka}$ AP sobre o en cercanías del punto de hallazgo. Todos estos elementos geológicos deben tenerse en cuenta al considerar dataciones y al programar otras nuevas. Una hipótesis posible es entonces la existencia de un sitio multicomponente con invasión por enterratorio de sitios más antiguos y de funcionalidad diferente. La presencia de carbón abundante y huesos con fracturas antrópicas distribuidos en área, de confirmarse, permite suponer, para Frías I, la presencia de un nivel inferior de ocupación in situ o con un cierto componente de retrabajo fluvial y sensiblemente más antiguo. Mientras que Frías II, podría ser un enterratorio totalmente desvinculado de Frías I.
Lamentablemente la datación de restos humanos por contexto estratigráfico en loess y loessoides rojizos, sin considerar su formación reciente por retransporte fluvial o eólico en dunas tipo lunette, más la no consideración de enterramientos intrusivos, se seguía utilizando hasta bien entrado el siglo XX con graves consecuencias paleoantropológicas. Un ejemplo de todo ello son los restos del arroyo Siasgo (Willis, 1912) donde nuevamente Ameghino atribuye gran antigüedad a los restos humanos por el solo hecho de estar en facies de limos rojizos que siempre interpretó, erróneamente en la pampa, como pliocenos.

En la fig. 32 se presenta un modelo geológico generalizado para la Pampa Ondulada donde se señala la posición estratigráfica de Frías I y Frías II (sensu Leheman-Nitsche, 1907) según las descripciones bibliográficas respecto a las secuencias deposicionales (Toledo 2011). También se indica la posición estratigráfica de los "paraderos" de Ameghino deducida a partir de los perfiles de Ameghino y sus descripciones litológicas.

\section{La colección "antropológica” de Ameghino del valle del Luján}

Ameghino siempre destacó la diferencia entre su colección "paleontológica" de la "antropológica". Si bien ambas fueron enviadas y exhibidas en París en 1878 solo la colección paleontológica fue vendida para solventar los gastos de estadía y publicación en Paris de manuscritos, que ya tenía preparados en Mercedes, principalmente de su obra culmine sobre sus investigaciones en el río Luján, "La antigüedad del hombre en el Plata". Igualmente Ameghino es comisionado para vender las otras colecciones particulares, entre ellas la de Bonemment, práctica considerada normal en el siglo XIX y regida por la ley del mercado (Richard 2008:129). De ello se han ocupado diversos y numerosos biógrafos y la información al respecto se encuentra publicada en su correspondencia (OCyCC, Vol. I, cartas 39, 49) y en carta de Ameghino a Zeballos del 10 de octubre de 1978 (ByAEZ). En las OCyCC (Torcelli, 1913) encontramos que la carta $n^{\circ} 49$ es un borrador ya que Zeballos no le facilitó la correspondencia con Ameghino a Torcelli, de hecho solo tres personas habrían respondido a su pedido para publicar en las OC y CC a su cargo, y vemos que Ameghino escribe pintorescamente "bolazo" en lugar de "disparate" al referirse a la supuesta venta de su colección antropológica. La carta definitiva que recibe Zeballos tiene un tono más medido y un cambio en el orden de los párrafos. Ameghino en 
su carta final prefiere poner en un segundo plano sus requerimientos sobre la nota de Zeballos y Reid (1976). Podgorny (2009:168) transcribe parcialmente la carta definitiva omitiendo el párrafo final donde Ameghino declara no haber vendido su colección antropológica. La transcripción completa se encuentra en Toledo (2009:113).

Ameghino no vende su colección de objetos relativos al hombre ya que era la base material que testimoniaba su hipótesis más preciada, la coexistencia del mismo con la megafauna. En París se entera por diarios argentinos de que él habría vendido dicha colección a un alto precio y no duda en escribir a Zeballos y calificar de "disparate" tales afirmaciones, pidiéndole que las desmienta en el diario La Prensa. Es extraño, a no ser que haya confundido ambas colecciones en una, que Podgorny (2000:31) sentencia inapelablemente a Ameghino de haber mentido, cuasi sin escrúpulos, a Zeballos. Ameghino no mintió, simplemente fue directo y sincero, no había vendido su colección, y como dijera en otras circunstancias a Moreno:

"Ud. debe conocer ya suficientemente mi carácter para comprender que lo que escribo es siempre la expresión fiel de lo que pienso" (OCy CC, Vol I, carta $\left.n^{\circ} 416\right)$

Ameghino vuelve a Buenos Aires en 1881 con esta colección enriquecida con una colección de líticos y calcos europeos que adquiere con sus propios medios. En su ausencia su hermano Carlos continúo la recolección de fósiles haciéndose de una nueva colección paleontológica Lujanense. En la correspondencia con Moreno hay una expresa referencia a ella pues el director del Museo de la Plata al anunciarle su nombramiento oficial como secretario sub-director, da por sentado la compra de sus colecciones y, contando de hecho con un gentlemen agreement previo a una tasación y acuerdo de precios, coordina por telegrama a Luján el envío de esas colecciones por tren. Ameghino se encontraba en esa villa y las despacha el 7 de julio 1886 (OCyCC, Vol. 20, cartas 414 a 418). Quedan así sus nuevas colecciones paleontológicas de Luján, las de sus paraderos, más de otras provincias (ver Farro, 2009:104), incorporadas al Museo Nacional de La Plata en Julio de 1886 donde una parte de ellas fueron exhibidas, otras archivadas e internamente dispersadas luego de estudios puntuales por distintos investigadores de dicha institución. Actualmente con faltantes, una parte, la correspondiente a los "paraderos eolíticos" del río Luján y los líticos
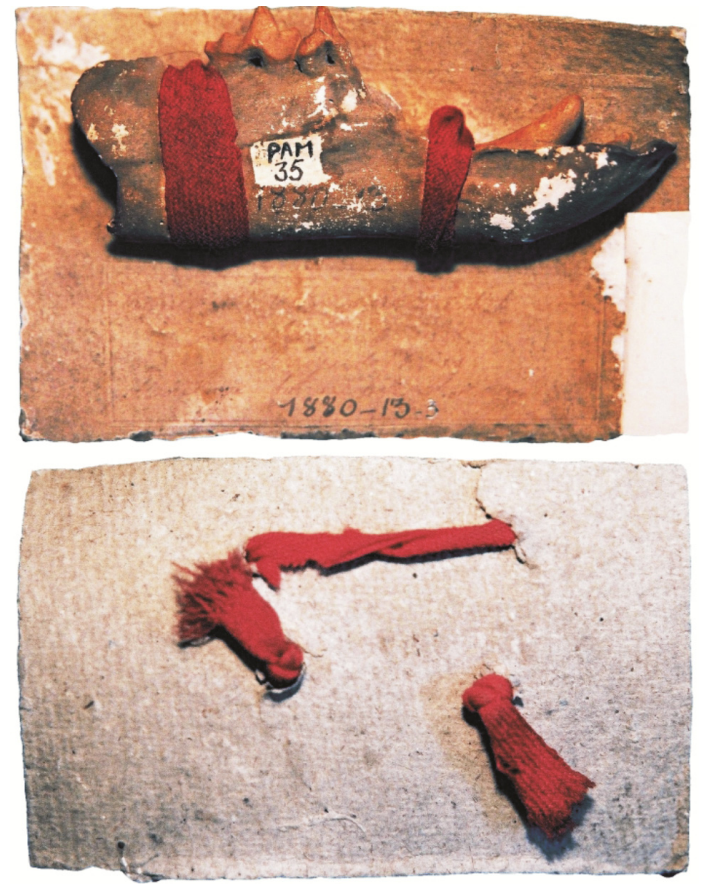

Fig. 33. Cartón original con etiqueta manuscrita por Ameghino de un molde donado en 1880 al MNHN de Paris (Pam 35).

europeos se encuentra en el Museo Nacional de La Plata. La colección "mesolítica" de Cañada de Rocha se encuentra separada, los restos óseos en esta última institución y parte de los líticos asociados en el INALP.

En 1907 Lehmann-Nitsche, a cargo de División de Antropología, las estudia y fotografía con la asistencia personal de Ameghino (Lehmann-Nitsche, 1907:145). Este autor precisa que numerosas piezas podían identificase ya que tenían el número original del "Catálogo Especial" de la exposición de París de 1878 o por comparación con los grabados de "La antigüedad del hombre en el Plata" (Ameghino, 1881). Un cierto número de fragmentos óseos no poseía número identificatorio y Lehmann-Nitsche (1907) confirma que la colección aún se encontraba, como posiblemente se exhibió en París, montada en cartones. En efecto al examinar la colección encontramos restos de "mastic" amarillento en numerosas piezas (e.g. fig. $34 \mathrm{n}^{\circ} 646$ derecho) y al desmontarse esta colección se ha conservado un fragmento de dichos cartones con anotaciones de Ameghino (Fig. 34). Ameghino también utilizaba hilo o cintas de tela para fijar piezas a un cartón (Fig. 33). El mastic se encuentra en el lado convexo o cortical de los fragmentos óseos 


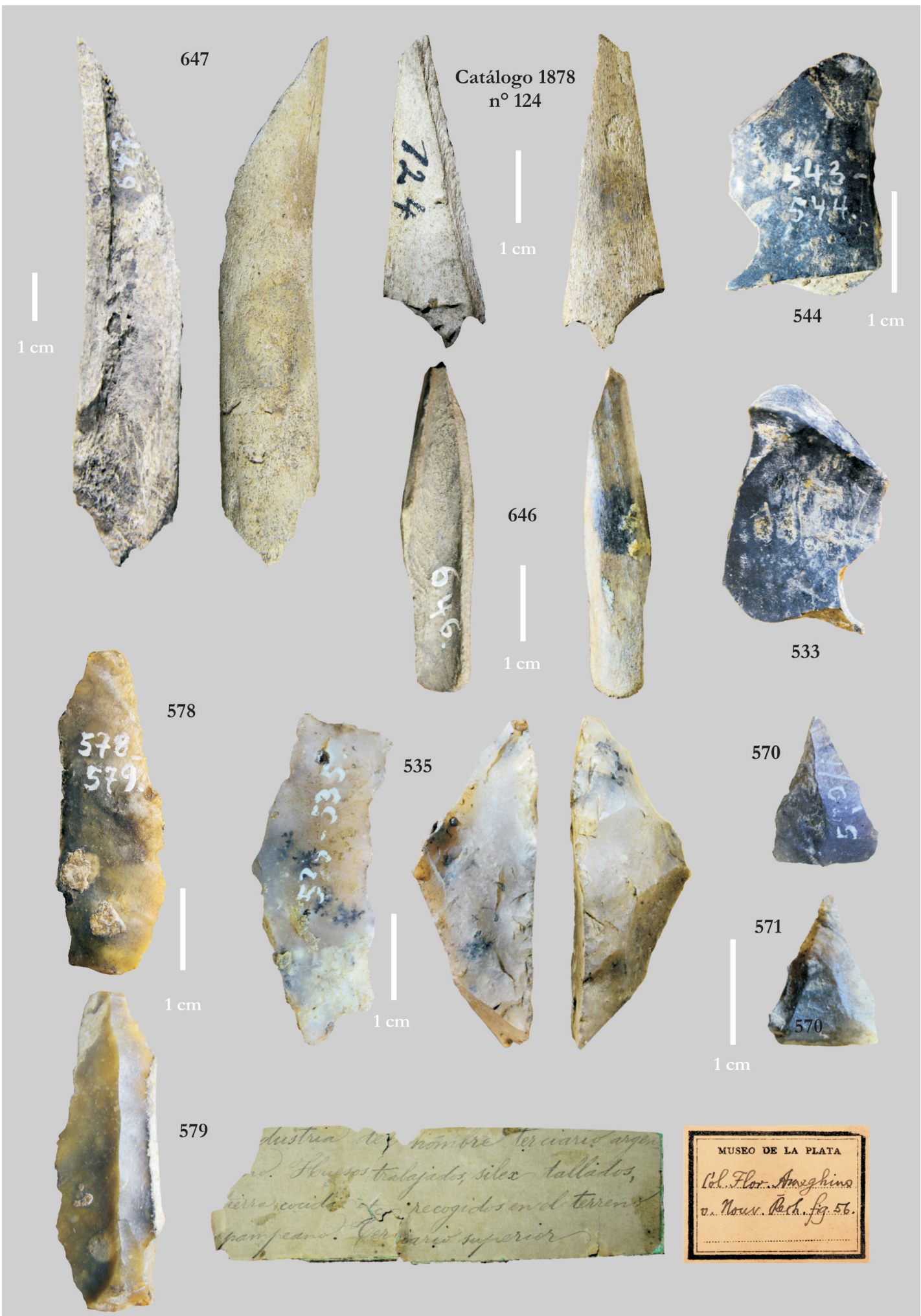

Fig. 34. Restos Óseos y artefactos líticos del sitio "eolíticos” del hombre de Frías II, capa 9 (Ameghino, 1881). 
y dentales de forma que quedaran exhibidos el canal medular con las fracturas en hueso fresco. Varios fragmentos no conservan restos de mastic pero se observa una aureola en el lugar donde se encontraba el mismo. El mastic se fabricaba con cera y yeso y se aplicaba en caliente (José Laza, com. pers.). En la fig. 34 se puede observar una inscripción o leyenda manuscrita por Ameghino que utilizó en uno de sus "cartones" donde exponía los restos óseos y líticos de sus "paraderos". Fue recortada y conservada al ser desmontada la colección de su soporte original a principios del siglo XX. Muy probablemente corresponde a uno los "cartones" exhibidos en la exposición de París. A su derecha mostramos la etiqueta manuscrita por Lehmann-Nitsche al reagrupar por "paradero" las piezas de la colección Ameghino para su revisión y estudio. La descripción y fotografías de las mismas serán publicadas en 1907 en su "Nouvelles Recherches sur la Formation Pampéenne". En particular los ejemplares de restos óseos modificados y artefactos líticos de Frías aparecen en la página 413, figura 56 (Fig. 34).

Las piezas que estudia y fotografía LehmannNitsche las rotula en blanco con la numeración de La Antigüedad que no coincide con la del catálogo de 1878 ni con una primera lista presentada a la Sociedad Científica Argentina (Ameghino, 1876).

El material se encuentra preservado en El Museo Nacional de Ciencias Naturales de La Plata en la colección Ameghino (MLP-arColección Ameghino, depósito 25). Se compone de restos óseos y líticos de sus sitios o "paraderos" 1 al 7 del valle del río Luján. Varias piezas pueden identificarse por los grabados de La Antigüedad del hombre en el Plata de las láminas XIX a XXIV $\mathrm{y}$ otras piezas no tienen identificación pero serian elementos de la misma procedencia no utilizados por Ameghino en sus publicaciones, así lo supone también Lehmann-Nitsche (1907, p. 410) al atribuirlos probablemente a los sitios (paraderos) I a II. El material del sitio Frias identificado, descripto y fotografiado por este autor se encuentra con la numeración de los grabados de La Antigüedad en blanco. Se compone de tres líticos, tres fragmentos óseos y un fragmento dental. Todos ellos fueron fotografiados y estudiados por Lehmann-Nitsche en 1907 y no habrían sido examinados por Hrdlicka en su visita de 1910 ya que si bien ofrece una breve descripción ésta habría sido hecha basada en el texto de Ameghino y sus grabados o "ilustration" (Hrdlicka, 1912). En varios de ellos se puede identificar aun adheridas arenas finas limosas verdosas y rojas, similares a las de los depósitos "Lujanenses" (Toledo, 2011).
La mayoría de estos restos son rombos de percusión por carga dinámica en hueso fresco comunes en las secuencias Luján (Toledo, 2009).

\section{Contenido arqueológico del sitio Frías I (Ameghino 1881)}

Restos óseos (capa 9). Ameghino menciona que encuentra en la "capa $n^{\circ} 9$ " una cantidad importante de huesos la mayoría con fractura longitudinal y escasa marcas de corte. El carbón es abundante. Los huesos rayados no los describe por considerarlos minoritarios y se concentra en las piezas $n^{\circ} 610,646$ y 647 que constituyen claros rombos de fractura por carga dinámica en hueso fresco con morfología helicoidal. En las piezas 613 y 614 se observan cavidades que describe como estigmas de percusión pero la calidad de los grabados no permite un análisis correcto de los mismos. Los ejemplares 610, 613 y 614 no se encuentran en las colecciones actuales y ya estaban perdidos al momento que LehmannNitsche examina la colección.

La pieza 647 posee dimensiones de $9,8 \times 1,5$ centímetros y constituye un fragmento de diáfisis con fractura helicoidal y posee sedimento de tipo loessoide, arenas muy finas limosas rojizas aun adheridas contra el tejido esponjoso. No posee rayas de corte ou otras modificaciones.

El ejemplar 646 es del mismo tipo con un menor grado de meteorización que el anterior. Posee dimensiones de $4,7 \times 1 \mathrm{~cm}$, rayas de corte muy finas de tipo slice marks y conserva aún mastic de tono amarillento con el que Ameghino presentaba estas "esquirlas" pegadas a un cartón.

La pieza 124 es un fragmento triangular con fractura en hueso fresco, de 4,4 x 1,3 centímetros, y tiene una particularidad patrimonial ya que conserva el primitivo sistema de numeración de la mano de Ameghino en tinta china o similar. Esta numeración corresponde con el catálogo de la Exposición Universal París de 1878 como señala Lehman-Nistche. Al examinar dicho catálogo para esta y otras piezas que aún conservan números en tinta negra directamente sobre la superficie ósea, comprobamos que figuraba en el grupo de piezas catalogado como " 121 a 127 " de "ossments longs fendus pour en extraire la moelle (sta. h. n1)". La "station humaine 1" corresponde con el "paradero 1" o sitio de Frías. Por otro lado hay que señalar que la pieza 124 no figura en los grabados de La Antigüedad del Hombre en el Plata (Ameghino, 1881).

Los fragmentos óseos 647,646 y 124 provendrían de fractura de la diáfisis en hueso fresco 


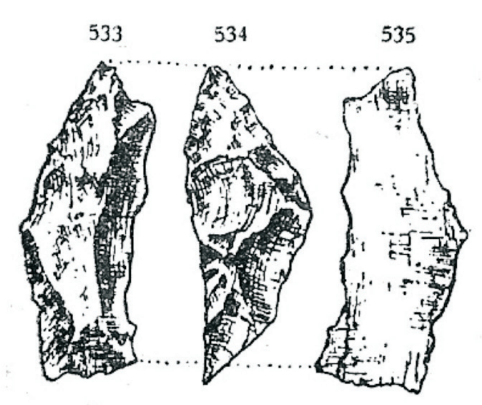

533-535

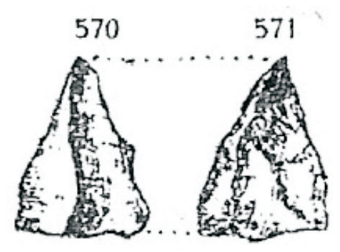

570-571

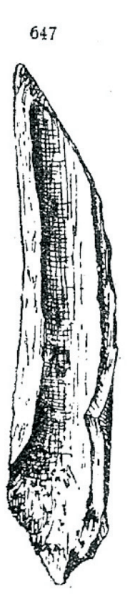

647

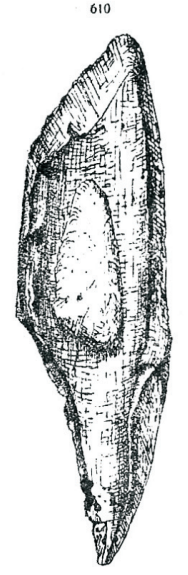

610

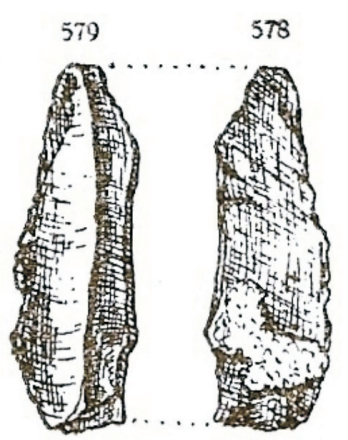

579-578

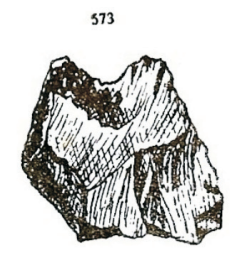

573

613

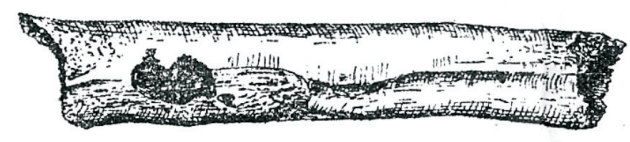

614

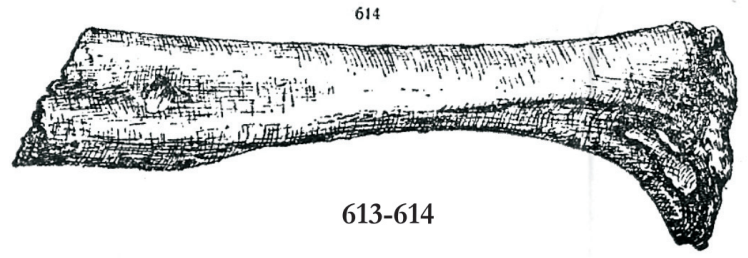

646
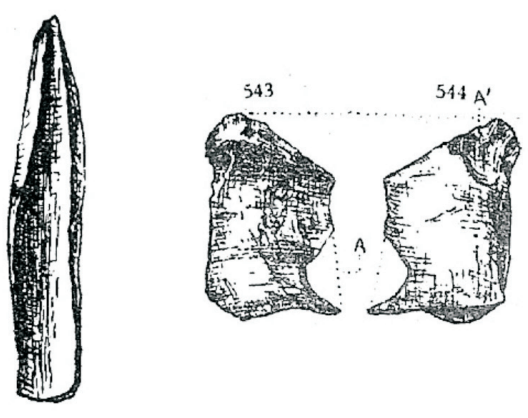

646

$543-544$

Fig. 35. Grabados de restos óseos y líticos del sitio del hombre del arroyo Frías. La antigüedad del hombre en el Plata (Ameghino, 1881).

para la extracción de la médula.

Es interesante detenerse sobre la pieza 543544 (Fig. 34 y 35), que es un fragmento de diente de Toxodon de 2,5 x 1,6 centímetros. Ameghino refiere que se observa el bulbo de percusión y que es muy delgado, interpretándolo entonces como una lasca. La observación directa de esta pieza permite confirmar la descripción de Ameghino (1881:488) respecto a la existencia de dicho bulbo, las fracturas modernas accidentales y la incrustación de carbonato de calcio. En repetidas oportunidades este autor menciona dientes 
modificados, en sitios del valle del río Luján, por percusión e incisión (Ameghino 1881, piezas 543, $545,656,436,437$ y 440 ). Es de destacar que las piezas dentales del Toxodon tienen grandes dimensiones y se podrían producir accidentalmente, en combates entre machos en la selección para el apareamiento, lascas de tamaño considerable con bordes muy cortantes en el esmalte. Por otro lado no debe descartarse, por las mismas características y como lo supone Ameghino, la posibilidad de obtención intencional de lascas con bordes cortantes en el esmalte y su utilización en herramientas expeditivas (Toledo 2009:182). Entre las referencias históricas, Vignati (1931) no descarta el origen antrópico de modificaciones en dientes de Toxodon recogidos en el valle de Tapalqué por Kraglievich, muy probablemente en la Secuencia Luján Verde superior o Miembro Guerrero, actividad que denomina "odontotecnia".

Líticos (capa 9). Junto a los restos de mamíferos fósiles y huesos humanos Ameghino (1881) menciona que encuentra "sílex tallados" y "mezclados" a los demás restos. Exhuma cuatro artefactos líticos en total, uno de ellos lo describe como una "cuarcita" (573), o "pedernal" en publicaciones o catálogos anteriores a 1881, y los restantes los describe como "sílex" (578-579, $535-534$ y 570). Actualmente se conservan todos ellos en la colección Ameghino del Museo de La Plata (MLP-Ar-col. Ameghino) a excepción de la pieza $n^{\circ} 573$ que la describe como una "cuarcita amarillenta" con concreciones oscuras que interpreta como tierra negra quemada, aunque puede también ser óxidos de manganeso ya que el material de Cañada de Rocha que Ameghino describe como "carbón", es en algunos casos, un complejo oscuro de óxidos (Toledo, 2009). Según los grabados, no posee una forma definida, ni retoques y se asemeja a un residuo de talla.

Los restantes tres artefactos pudieron ser observados en la colección citada: El artefacto 535534 es una ftanita blanquecina con un largo de $3,7 \mathrm{~cm} \times 1,3 \mathrm{~cm}$ de ancho x 1,3 de alto, de sección triangular y base ventral plana. Parece ser un fragmento de una herramienta mayor de filos de alto ángulo como un cepillo. Posee microlasqueado por uso.

La pieza lítica $570-571$ es una ftanita gris bandeada, triangular de dimensiones de 1,65 x 1,2 centímetros. Es una lasca con filos naturales y presenta restos de sedimentos loessoides.

La pieza 578-579 es una de lámina de ftanita de $3,75 \times 1,25$ centímetros de sección triangular de tonalidad verdosa, con bulbo de percusión, cara ventral plana, filos naturales y restos corti- cales. Posee incrustaciones de $\mathrm{CaCO}_{3}$. En el interior se observan numerosas partículas flotantes en la matriz silícea, algunas de ellas organizadas, indeterminables y de probable origen biológico.

Estas piezas fueron fotografiadas por Lehman-Nistche en 1906 en el Museo de La Plata y formaron parte de las primeras colecciones de Ameghino presentadas en los concurso de la Sociedad Científica Argentina (1875) en el Colegio Nacional, acompañaron la memoria " $E l$ hombre cuaternario en la Pampa" elevado a la misma sociedad en 1876 con los números 25,26 , y 27 (silex) y 28 (pedernal); y figuraron en la exposición de Paris con numero de catálogo 57, 58 y 50 (silex) y 60 (pedernal).

Hrdlicka (1912:207) en su revisión de los descubrimientos de Frías describe precipitadamente y de forma sesgada todos estos artefactos como unifaciales ("worked-on-one-face-only-type") por lo que los asimila a los artefactos líticos de tribus contemporáneas y así descarta toda antigüedad posible de sitio Frías.

\section{DISCUSIÓN}

\section{Sobre la edad}

Los biógrafos de Ameghino, hagiográficos o no, generalmente veían en las atribuciones de edad pliocena o terciaria para la formación pampeana un exceso temerario de ese autor, sin ahondar en el origen de dicha atribución. Sin embrago, Ameghino (1881) dedicó a la cuestión de la edad un capítulo entero, el XIII, donde detalló sus criterios cronológicos. Su razonamiento fue el siguiente: en Europa el Cuaternario o "diluvium" (Buckland, 1823) correspondía al período glacial. Como en la pampa no encontraba elementos geológicos para definir depósitos glaciales, utiliza el criterio del índice de especies extintas respecto al total de especies de una formación dada. Si bien se sabe hoy que esta relación no es válida entre los dos continentes, es destacable el razonamiento científico seguido con los datos disponibles en la época. Ameghino siguió este razonamiento riguroso aplicando en la pampa el mismo índice que usaba Lyell en Europa para determinar cronologías relativas: el porcentaje de especies extinguidas de cada formación respecto a las que se encontraban en su techo y base. Así Ameghino hace un escrupuloso análisis comparativo, entre otras consideraciones geomorfológicas y paleontológicas, de los porcentajes de fauna extinta de las formaciones Patagónica, Pampeana y Post pampeana, y los compara con los porcentajes del Mioceno, 
Plioceno y Cuaternario europeos. Concluye que la Formación Pampeana posee un $90 \%$ de especies extintas, similar al porcentaje del Plioceno europeo. De este modo, deduce y defiende categóricamente la edad pliocena de su Formación Pampeana. Con la misma línea de pensamiento asigna el "Postpampeano" al Cuaternario, y por lo tanto lo hace contemporáneo al "Período Glacial". Por otro lado, Ameghino va a confundir los depósitos rojizos que aparecen en el corte de Frías, con los de su "Pampeano Superior", hoy Formación Buenos Aires, con los limos loessoides de similar aspecto de la Formación Luján (Toledo, 2011). Esta errónea atribución estratigráfica, que es comprensible para la época teniendo en cuenta la indisponibilidad de dataciones y afloramientos más continuos, llevó a Ameghino al convencimiento de haber hallado en América fósiles humanos de edad "Pliocena".

\section{Sobre el contexto social}

Respecto al contexto social en que Ameghino se desenvolvió y su lectura posterior, la historiografía de la obra ameghiniana ha pasado por un periodo de construcción de un héroe ejemplar en las décadas posteriores a su muerte, luego un intervalo de olvido e indiferencia por la sociedad, mientras que era considerado una "gravosa carga" (Orquera, 1971) para ciertos círculos académicos, para ingresar a fines del siglo XX a un periodo de revisionismo de su canonización civil (Salvatore, 2007; Podgorny, 2009). Esta última etapa de análisis rescata valiosos aspectos olvidados, ignorados o conscientemente dejados de lado por sus biógrafos hagiográficos, pero insiste y fuerza a su vez en amalgamarlo como un elemento más en una red de prácticas colectivas. Reparados los errores de los compiladores de elogios, los nuevos modelos tienden a banalizar su singularidad, en particular para el periodo más temprano, anterior a 1882 . En este periodo inicial Ameghino, como Tournal, no serán aceptados ni reconocidos en las redes académicas de ciencia central u oficial. El intercambio de misivas, el envío de pruebas materiales y aun el lograr publicar notas científicas, todas ellas prácticas aparentemente colectivas, no les garantizó ni significó que pasaran a integrar y ser parte activa de los círculos que disponían, o demoraban, la certificación y aceptación de sus investigaciones. No se debería poner en igualdad de análisis a un Ameghino, a un Tournal y a un Boucher des Perthes con integrantes funcionales a dichas redes como los comerciantes de fósiles y antigüedades. Estos poseían un interés directo para los círculos centrales como proveedores y la relación era intensa e interesada regida por estrategias comerciales de un lado y en la contraparte la necesidad, frecuentemente urgente, de las piezas ofrecidas. En contraste con estas prácticas los estudiosos provinciales o periféricos, periféricos ya sea por distancia, por su juventud, por falta de educación científica formal o por no pertenecer a instituciones reconocidas demandaban un producto moral: la certificación, la aceptación y la legitimación de sus ideas y de las observaciones de campo originales. Comprender las redes de intercambio de objetos y conocimientos, y la constitución de sus grupos formales e informales y, sus distancias relativas, fue y es un gran avance en la compresión de los procesos de creación de conocimiento, pero en el caso que nos ocupa es necesario distinguir los actores que interactuaban "en" las redes de los que interactuaban "con" las redes.

\section{Sobre el contenido de los sitios}

Pasando al análisis del contenido cultural de sus sitios, principalmente restos óseos modificados, Ameghino antes de su viaje a Europa, lejos de crear su propia arqueología, contaba con las descripciones e ilustraciones de obras como las de Gervais y Figuier que estaban disponibles en la biblioteca del Museo Público, además del testimonio directo de Ramorino y a efectos comparativos los restos recuperados en Cañada de Rocha. En cuanto al contenido lítico, Ameghino no podía dudar de su origen antrópico no solo por la formatización antrópica evidente, sino también por la lejanía de las áreas de aprovisionamiento y las características geomorfológicas que descartan toda conexión fluvial del valle del río Luján con alguna de ellas. $\mathrm{Al}$ respecto, este valle se encuentra en un área que depende del aprovisionamiento lítico de larga distancia mixto, es decir con posibles fuentes en Tandilia al sur (ftanitas, ortocuarcitas y dolomías silicificadas), el área del Río Uruguay inferior (ftanitas) al norte y posiblemente de las Sierras Pampeanas (cuarzo y rocas metamórficas) al noroeste. En particular para la ftanita, que predomina en la colección Ameghino, las fuentes conocidas son las de la Formación Cerro Largo del Precámbrico de Tandilia (Mesineo et al., 2004) y las de las Formaciones Puerto Yerua (Entre Ríos) y Mercedes (Uruguay) del Cretácico terminal (Bossi et al., 1975, Tófalo y Pazos, 2002). Estas últimas son calizas lacustres con niveles silicificados por lo que contienen microfósiles a diferencia de las ftanitas precámbricas microcristalinas (Poiré com. pers., 2016). El uso de ftanitas originarias del área de 
Entre Ríos y occidente uruguayo tiene registro arqueológico comprobado en la región pampeana (Flegenheimer et al., 2003; Martínez, 2001; Loponte et al., 2010; Nami, 2016).

La revisión de la estratigrafía, su cronología y el estudio de colecciones de los sitios del río Luján indican que en su conjunto las observaciones tafonómicas y estratigráficas fueron notablemente acertadas para el contexto histórico en el que fueron realizadas. Debe revalorizarse la actividad pionera de Ameghino en cuanto el análisis tafonómico de fauna pleistocena ya que realizó estudios sistemáticos que incluyeron la comparación con material de sitios recientes, indudablemente antrópicos, la experimentación y la descripción morfológica detallada acompañada de ilustraciones.

Se corrobora que en líneas generales la "capas" de Ameghino se reconocen en los afloramientos entre Luján y Mercedes, que las modificaciones óseas son antrópicas, que en la mayoría de los casos la concentración de material se debe a procesos fluviales, y por ello el término histórico "paradero" queda desvirtuado como posible sitio primario. Los modelos estratigráficos actuales, la revisión de colecciones de museos y nuevos elementos recogidos in situ implicaría que la ocupación inicial de este valle tendría una edad mínima sensiblemente anterior al Ultimo Máximo Glacial (Toledo, 2009, 2010, 2011).

Sin duda víctimas del informe de Zeballos y Reid (1876), de la visión impuesta por Hrdlicka (1912), y de la revisión de Orquera (1970, 1971), los restos serán considerados de poca antigüedad y un ejemplo más de las inconsistencias ameghinianas. Las escaramuzas con la SCA, que llevaron a confundir al sitio de Rocha con el de Arroyo Frías y el del paso de Azpeitia, tuvieron graves consecuencias para el futuro de la arqueología pampeana, que se reflejan aún en la actualidad, perdiéndose una oportunidad inmejorable para la fundación temprana de una escuela arqueológica argentina (Fernández, 1982:82).

Este autor afirmaba con acierto, aún antes del inicio hacia mediados de los 1980's de un nuevo período de revisión, con metodología moderna y bajo paradigmas sistémicos, de los sitios bonaerenses:

"bajo el loess y el limo de las pampas infinitas, oculta su verdadera fisonomía el más enigmático y acuciante desafío que aún resta en pie para los arqueólogos del futuro". (Fernández 1982:93).
Esta visión y su desafío han sido materializados parcialmente y a la sombra de los limitantes cronológicos impuestos por los paradigmas de poblamiento "pre Clovis" inicialmente y el de poblamiento "Post LGM", dominante en la actualidad (ver Politis, 2015, para una defensa entusiasta de esta posición). El desafío y llamado de Ameghino para aceptar o rechazar sus hallazgos en los depósitos del Pleistoceno terminal del valle del río Luján sigue aún vigente. A diferencia de otras regiones la no existencia de material lítico local y la baja energía de los paleoambientes deposicionales disminuyen ostensiblemente los factores de (ambigua) ambigüedad sensu Borrero (2016).

\section{CONCLUSIONES}

La revisión histórica y geoarqueológica del área del sitio Frías permite establecer que:

- La localización geográfica equivocada del sitio de Frías más su confusión con el sitio de Rocha, materializadas en las publicaciones de la SCA, no fue rectificada a pesar de las inmediatas aclaraciones de Ameghino. Esto desvalorizó e hizo caer en el olvido todos los sitios no holocenos del valle del río Luján.

- La gran antigüedad otorgada por Ameghino a los restos de Frías se explica por el desarrollo importante de las facies rojizas de la secuencia Luján Rojo fácilmente confundible con el sustrato "pampeano superior" o actual Formación Buenos Aires. (Toledo, 2011b).

- El punto del hallazgo se encontraría en las cercanías del puente "de hierro" o "viejo" actual. Las descripciones geomorfológicas de Ameghino no coinciden con las actuales de dicha área.

- Los sedimentos portadores de material cultural, intrusivo o no, posen edades entre 15 y 30 ka AP.

- Hacia 11 ka AP no existía el arroyo inciso actual y el punto de hallazgo se encontraba en la periferia de un humedal instalado en el valle del Luján y afluentes colmatados. Esto debe ser tenido en cuenta para futuras prospecciones y perfilados estratigráficos.

- La mezcla de material entre las diferentes intervenciones de Ameghino, como propone Orquera $(1970,1971)$, parece muy poco probable y simplificadora. Se propone como hipótesis de trabajo la superposición e intrusión de más de un nivel cultural con distintas edades y funcionalidades. 


\section{AGRADECIMIENTOS}

Por diversas contribuciones se desea agradecer a: la Dra. M. A. Peltrin, el Sr. J. Petroccelli (Mercedes), la Srta. M. Luchetti (Archivo y Biblioteca E. Zeballos, Luján), la Sra. E. Furt $(\dagger)$ (Biblioteca y Archivo Furt), a la Dra. Ruth Gruhn y a la Sra Beatriz Campi de Mouhsen y al Sr Carlos A. Dagnino de Mercedes.

Este trabajo esta basado en un capitulo de la tesis doctoral del autor (Toledo, 2009) y una primera version fue presentada en octubre de 2011 en el complejo cultural Marín de Mercedes en homenaje del centenario del fallecimiento de Florentino Ameghino.

\section{BIBLIOGRAFÍA}

Ameghino, F. 1875. Nouveaux débris de l'homme et de son industrie, mêlés à des ossements d'animaux quaternaires, Recueillis auprès de Mercedes (République Argentine). Journal de Zoologie, IV: 527-528.

Ameghino, F. 1876. El hombre cuaternario en la Pampa. Primeros trabajos científicos. En Torcelli A. (ed.) Obras Completas. Taller de impresiones oficiales (1914), Vol. 2, 340 pp., La Plata.

Ameghino, F. 1876. El hombre cuaternario en la Pampa. Primeros trabajos científicos. En: Torcelli A., 1914(Ed.), Obras Completas. Vol. I. Taller de impresiones oficiales, 340 pp., La Plata.

Ameghino, F. 1876-1886. Recortes de diarios del autor. Legajo Ameghino. Biblioteca Furt, Los Talas. Luján

Ameghino, F., 1877. Noticias Sobre Antigüedades Indias en la Banda Oriental, con Tres Láminas Representado Objetos de Piedra de la Edad Neolítica. Imprenta de La Aspiración, Mercedes, $80 \mathrm{pp}$.

Ameghino, F. 1878. L'Homme préhistorique dans le bassin de la Plata. En : Comptes rendus sténographiques du Congrès lnternational des Sciences Anthropologiques, tenu à Paris du 16 au 21 Août 1878., pp. 341-350, París.

Ameghino, F. 1879a. L'homme préhistorique dans la Plata. Revue d'Anthropologie 2(2): 237-249.

Ameghino, F. 1879b. La plus haute Antiquité de l'homme dans le nouveau-monde. Congrès international d'américanistes. Compte rendu de la troisième session. (2): 198-239. Bruxelles

Ameghino, F. 1880b. Armes et instruments de l'homme préhistorique des Pampas. Revue d'Anthropologie. II3:1- 12 .

Ameghino, F. 1880b. La Antigüedad del Hombre en el Plata. Tomo I. G. Masson e Igon Ed. París-Buenos Aires, $640 \mathrm{pp}$.

Ameghino, F. 1881. La Antigüedad del Hombre en el Plata. Tomo II. G. Masson e Igon Ed. París-Buenos Aires, $552 \mathrm{pp}$.

Ameghino, F. 1889. Contribución al conocimiento de los mamíferos fósiles de la República Argentina. Actas de la Academia Nacional de Ciencias (Córdoba) 6 : 1-1028 y Atlas: 98 láminas.

Ameghino, F. 1918. La Antigüedad del Hombre en el Plata. Parte primera y segunda. La Cultura Argentina-Buenos Aires.

Ameghino, F., 1880 a. Armes et instruments de l'homme préhistorique des Pampas. Revue d'anthropologie. II-3:1-12.

Hurel A. 2011. Paul Tournal, les grottes de Bize et la question de la haute antiquité de l'homme. En Hurel A. \& Coye N. Eds., Dans l'épaisseur du temps. Archéologues et géologues inventent la Préhistoire. Paris, Publications scientifiques du Muséum, 2011, P 109.

Borrero, L. A. 2015. Con lo mínimo: los debates sobre el poblamiento de América del Sur. Intersecciones en Antropología, 16(1). Olavarría

Borrero, L. A. 2016. Ambiguity and Debates on the Early Peopling of South America. Paleoamerica 2(1): 11-21.

Bossi, J.; L. Ferrando, A. Fernández; G. Elizalde, H. Morales, J. Ledesma; E. Carballo, E. Medina; I. Ford \& J. Montaña. 1975. Carta Geológica del Uruguay. Montevideo, Dirección Suelos y Fertilizantes, Ministerio de Agricultura y Pesca.

Buckland, W., 1824. Reliquiae diluvianae. $2^{\text {nd }}$ edition, London.

Camacho, H.H., 1971. Las ciencias naturales en la Universidad de Buenos Aires. Estudio histórico. Editorial Universitaria de Buenos Aires, Buenos Aires.

Casinos A. 2012. Un evolucionista en el Plata. Fundación Azara, 430pp.

Dagnino C.A. 2014. Los antiguos caminos rurales. Diario El Oeste. $1^{\circ}$ de Julio de 2014 . Mercedes.

de Mortillet, G., 1873. Classification des diverses périodes de l'âge de la pierre. En : Congrès international d'anthropologie et d'archéologie préhistoriques, Comptes rendus de la 6e session, Bruxelles, 1872. Bruxelles : C. Muquardt, p. 432-459.

De Groote, I. et al. 2016. New genetic and morphological evidence suggests a single hoaxer created 'Piltdown man'. Royal Society open sci.3: 160328. http://dx.doi.org/10.1098/rsos.160328.

Farro, M. 2009. La formación del Museo de La Plata. Prehistoria Ediciones. Rosario, 230pp.

Fernández, J. 1982. Historia de la arqueología argentina. Asociación Cuyana de Antropología, Mendoza.

Figuier, L., 1873. L'Homme Primitif. Hachette, Paris, $492 \mathrm{pp}$.

Flegenheimer, N., C. Bayón, M. Valente, J. Baeza, \& J. Femenías. 2003. Long distance tool stone transport in Argentine Pampas. Quaternary International, 109-110 : 49-64.

Gervais, P. 1867 Recherches sur l'ancienneté de l'homme et la période quaternaire. A. Bertrand, Paris.

Gervais, P. 1872. Debris humains recuellis dans la Confederation Argentine avec des ossements d'animaux appartenant a des especes perdues. Journal de Zoologie, II : 231-234. 
Hamy, M., 1870. Précis de paléontologie humaine. J.B. Bailliere et fils, Paris, 372 pp.

Hrdlicka, A. 1912. Early men in South America. Smithonian Institution. Bureau of American Ethnology. Bulletin 52. Washington, 405 pp.

Issel, A., 1864. Di una caverna ossifera di Finale. Atti dela Societa italiana di scienze naturali, vol. III, Milano.

Issel,A., 1875. L'Uomo preistoricoin Italia. En: Lubbock, I tempi preistorici e l'origine dell'incivilimento, pp. 735-916, Torino.

Laming-Emperaire, A. 1964. Origines de l'archéologie prehistorique en France. Ed. Picard. Paris, 241pp.

Lehmann-Nitsche, R. 1907. Nouvelles recherches sur la formation Pampéenne et l'homme fossile de la République Argentine. Buenos Aires. Revista del MuseodelaPlata. TomoXIV.Imprenta Conni, 490pp.

Lista, R. 1998. Obras. 2v., Confluencia, Buenos Aires.

Loponte, D., P. Tchilinguirian \& R. Sacur Silvestre. 2010. Caracterización de afloramientos de calizas silicificadas de la provincia de Entre Ríos (Argentina) y su vinculación con los circuitos de abastecimiento prehispánico. In: Feuillet, M.R., Terzaghi, M., Colasurdo, B., Sartori, J.I., Escudero, S. (Eds.), Avances y Perspectivas en la Arqueología del Nordeste, pp. 125-139, ST Productos Gráficos, Buenos Aires.

Martínez, G. 2001. "Fishtail" projectile points and megamammals: new evidence from Paso Otero 5 (Argentina). Antiquity 75(289): 523-528.

Messineo, P., M. Barros, D. Poiré \& L. Peral. 2004. Características litológicas de los niveles de chert o ftanitas en las Sierras Bayas (partido de Olavarría, provincia de Buenos Aires)'G. Martínez, M. Gutiérrez, R. Curtoni, M. Berón, P. Madrid (Eds.), Aproximaciones contemporáneas a la Arqueología pampeana. Perspectivas teóricas, metodológicas, analíticas y casos de estudio, pp. 305-317, Facultad de Ciencias Sociales, Olavarría.

Nami, H.G. 2013. Archaelogy, Paleoindian Research and Lithic Technology in the Middle Negro River, Central Uruguay. Archaeological Discovery Vol.1( 1):1-22

Nami, H. G. 2016. Silcrete as a valuable resource for stone tool manufacture and its use by PaleoAmerican hunter-gatherers in southeastern South America. Journal of Archaeological Science, en prensa, DOI: 10.1016 .

Orquera, L. A. 1970. A cien años del descubrimiento de Ameghino. Diario La Prensa, 6 de Septiembre de 1970. Buenos Aires

Orquera, L. A. 1971. Paleoantropología de la Pampa Húmeda. Universidad de Buenos Aires, Facultad de Filosofía y Letras. Buenos Aires, 384 pp. Inédito. Biblioteca del Museo Etnológico de Buenos Aires.

Outes, F. 1897. Los Querandíes. Buenos Aires. Imprenta de M. Biedma. 202 pp.

Podgorny, I. 2009. El sendero del tiempo y de las causas accidentales. Los espacios de la prehistoria en la Argentina, 1850-1910. Prohistoria ediciones, Rosario. 331pp.

Podgorny, I. 2014. El colmillo de Sarmiento. Recortes para una autobiografía de Florentino Ameghino. En: Florentino Ameghino en Mercedes. Homenaje en el centenario de su fallecimiento, pp. 47-62, MCA libros. Mercedes.

Politis, G., G. Barrientos, \& T. Stafford. 2011. Revisiting Ameghino: new ${ }^{14} \mathrm{C}$ dates from ancient human skeletons from the argentine pampas. En D. Vialou (Ed.), Peuplements et préhistoire en Amérique, pp 43-54, Editorial du CTHS, Paris.

Politis, G. \& M. Bonomo. 2011. Nuevos datos sobre el "hombre fósil" de Ameghino. En: Vida y Obra de Florentino Ameghino. Publicación especial 12, Asociación Paleontológica Argentina, pp 101-119.

Politis, G. 2015. Comentario 1. Un juego de metáforas .En Borrero, L. A. 2015. Con lo mínimo: los debates sobre el poblamiento de América del Sur. Intersecciones en Antropología, 16(1). Olavarría

Reimer,P.J., T.A. Brown \& R.W. Reimer. 2004. Discussion: Reporting and calibration of post-bomb 14C data. Lawrence Livermore National Laboratory, paper UCRL-JRNL-207168. Radiocarbon , DOI: http:// dx.doi.org/10.2458/azu_js_rc.46.4183.

Richard, N. 2008. Inventer la préhistoire. Les débuts de l'archéologie préhistorique en France. Vuibert, AdaptSnes, Paris. 235 pp.

Rudwick, M.J.S. 2008. Worlds before Adam. The reconstruction of geohistory in the age of reform. University of Chicago Press, Chicago, 614 pp.

Salvatore, D. R. 2007. Los Lugares del Saber. Contextos locales y redes transnacionales en la formación del conocimiento moderno (compilador). Beatriz Viterbo editora, Rosario

Toledo, M.J. 2009. Géoarchéologie de la transition Pléistocène-Holocène dans le nord-est pampéen (Buenos Aires, Argentine). Révision historique, stratigraphique et taphonomique. Perspectives pour le premier peuplement. Tesis doctoral, Muséum National d'Histoire Naturelle (inédita), París, 589 pp.

Schwenninger, JL. 2005-2008. OSL dating. Pampa Project. RLAHA. Oxford University, Oxford. Inédito.

Stagnaro, A. A. 1993. La antropología en la comunidad científica: entre el origen el hombre y la caza de cráneos-trofeo (1870-1910). Alteridades, 3(6):53-65.

Strobel, P. 1867. Paraderos preistorici in Patagonia. Atti de la Societa Italiana de Scienze Naturali, $\mathrm{X}: 167: 172$.

Strobel, P. 1872. Le valve degli Unio nelle mariere dell'emiliae nei Paraderos della Patagonia. Archivo per l'Antropologia et la Etnologia 16, pp. 272. Firenze

Tófalo, O. R. \& P. J. Pazos. 2002. Caracterización de calcretes de la Formación Puerto Yeruá (Cretácico), en base a su micromorfología (Entre Ríos, Argentina). Revista de la Asociación Argentina de Sedimentología 9 (2): 127-134.

Toledo, M.J. 2005. Secuencias Pleistocenas "Lujánenses" en su sección tipo: Primeras dataciones C14 e implicancias estratigráficas, arqueológicas e históricas, Luján-Jáuregui, provincia de Buenos Aires. Revista de la Asociación Geológica 
Argentina 60(2): 417-424.

Toledo, M.J. 2009. Géoarchéologie de la transition Pléistocène-Holocène dans le nord-est pampéen (Buenos Aires, Argentine). Révision historique, stratigraphique et taphonomique. Perspectives pour le premier peuplement. Tesis doctoral, Muséum National d'Histoire Naturelle (inédita), Paris 589 pp.

Toledo, M.J. 2005. Secuencias Pleistocenas "Lujánenses" en su sección tipo: Primeras dataciones C14 e implicancias estratigráficas, arqueológicas e históricas, Luján-Jáuregui, provincia de Buenos Aires. Revista de la Asociación Geológica Argentina 60(2): 417-424.

Toledo, M.J. 2010. "Black Mats" and extinctions: The Pleistocene-Holocene transition climatic crisis in central Argentina". 18th International Sedimentological Congress, Actas: pp 868, Mendoza.

Toledo, M.J. 2011a. El legado Lujanense de Ameghino: revisión estratigráfica de los depósitos pleistocenosholocenos del valle del río Luján en su sección tipo. Registro paleoclimático en pampa de los estadios OIS 4 al OIS 1. Revista de la Asociación Geológica Argentina, 68 (1):121-167.

Toledo, M.J. 2011b. "Loess man" pampeano: Nuevos datos históricos y geoarqueologícos de los hallazgos de Carcarañá, Fontezuelas, Baradero y Frías. Congreso de Arqueología de la Región Pampeana
Argentina. Libro de Resúmenes. pp.124. La Plata.

Toledo, M.J. \& J.L. Schewenninger. 2010. Loess and reworked loess: first evidences of the presence of OIS 4 deposits in ortheastern pampas valleys". 18th International Sedimentological Congress. Theme 11: Palaeoclimatology TS11-1. Quaternary climate archives. Abstracts.

Torcelli, A. 1935. Obras completas y correspondencia científica de Florentino Ameghino, Obras Póstumas y Truncas vol. 20. Taller de impresiones oficiales. La Plata.

Vignati, M.A. 1931. Descripción de un instrumento tallado en un diente de "Toxodon". Separata de Notas preliminares del museo de La Plata, Tomo 1:189196. Imprenta Coni. Buenos Aires

Zeballos, E. 1910. MS mecanografiado sin título. AyBEZ, 53pp.

Willis, B. 2012. Observations on the Arroyo Siasgo find. En: Hrdlicka, A., Early men in South America. Smithonian Institution. Bureau of American Etnology. Bulletin 52, pp 269-272, Washington .

Zeballos, E. 1879. Noticas preliminares sobre el hombre primitivo de la Provincia de Buenos Aires. Revista de Ciencias, Artes y Letras. 1(1):39-51.

Zeballos, E. \& W. Reid. 1876. Notas geológicas sobre una excursión a las cercanías de Luján. Anales de la Sociedad Científica Argentina, 1:313-319., Imp. E. Coni. Buenos Aires.

Doi: 10.22179/REVMACN.18.460

Recibido: 31-VIII-2016 Aceptado: 6-XII-2016 
